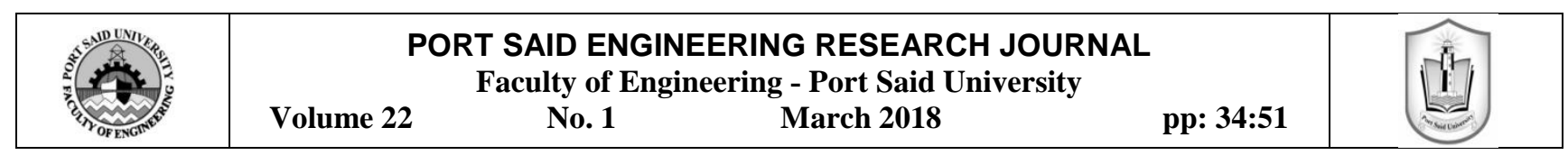

\title{
Integrated Coastal Zone Management in the North of Egypt A Case Study: Natural Gas Treatment Plant west of Port Said
}

\author{
E. Tolbal/T. Abu Lila²/A. Salem ${ }^{3}$
}

\section{ABSTRACT}

Coastal resource systems are valuable natural endowments that need to be managed for present and future generations. Integrated Coastal Zone Management (ICZM) promotes sustainable coastal development by adapting the use of natural resources in a way that avoids serious damage to the natural environment. ICZM seeks, over the long-term, to balance environmental, economic, social, cultural and recreational objectives, all within the limits set by natural dynamics. It aims to address the problems or issues that exist and exacerbate in the coastal zone including marine resource exploitation, pollution of estuarine and coastal waters, climate change and sea level rise, and coastal erosion. Accelerated erosion and deposition is the major concern problem in the Egyptian northern coasts induced basically by the over-development of the coastal areas and the improperly designed projects. These rapid and uncontrolled coastal developments for establishment and growth of industry, resource extraction, tourism and urbanization, involve harbors, recreational centers, protective structures, estuaries, and lagoon inlets.

At the northeastern coast of Egypt, precisely $12 \mathrm{~km}$ to the west of Port Said city, it is intended to construct a new natural gas treatment plant. Because of the available area is limited, it was decided to establish the flare stacks inside the sea. The flare stacks and the pipe racks will be connected to the plant through two causeways. Meanwhile, another marine structure, a temporary cofferdam, will be constructed for the purpose of installing gas pipelines under seabed extending from gas well located offshore to the onshore area where the new treatment plant exists. This research discusses shoreline evolution in the project area due to the construction of the causeways and the temporary cofferdam into the sea. Three methods had been followed to fulfill the aim of the current research: the numerical approach (using one-line LITPACK model); shoreline monitoring program; and shoreline verification using satellite images.

Keywords: ICZM; coastal development; erosion; causeways; shoreline evolution.

\section{INTRODUCTION}

Coastal zones have been greatly exploited by man for establishment and growth of industry, resource extraction, tourism and urbanization, which have led to several negative environmental impacts such as the effects of inappropriate industrial and human waste management, accelerated erosion and deposition, destruction of marine life and overall decrease of biodiversity, Fabbri (1998) [8]. Therefore, there is an urgent need for controlled development of this area. Integrated coastal management is a dynamic process by which decisions are taken for the use, development, and protection of coastal/marine areas and resources, CicinSain (1993) [3]. Kenchington and Crawford (1993) [12] defined the ICZM as the integration of environmental protection goals into economic and technical decisionmaking process. The goals of integrated coastal management are to attain sustainable development of coastal/marine areas, to reduce vulnerability of coastal areas to natural hazards, and to maintain essential ecological processes, life-support systems and biological diversity in marine/coastal areas, Cicin-Sain (1993) [3].

\footnotetext{
1 Professor, Faculty of Engineering, Port Said University, Egypt, Email: tolba_1966@yahoo.com

${ }^{2}$ Lecturer, Faculty of Engineering, Port Said University, Egypt, Email: eng tarek_selim@yahoo.com

${ }^{3}$ Demonstrator at the Higher Institute of Engineering and Technology, New Damietta, Egypt, Email: eng.asmaa.salem88@gmail.com
}

Rapid and uncontrolled coastal developments, together with improperly designed projects, have had a negative impact on the Egyptian coastal ecosystem. A number of coastal projects have been proposed along the Egyptian northern coast, not all of which have been eco-friendly. During the past three decades, important explorations of natural gas wells have been carried out in the Mediterranean offshore of Port Said city, Egypt. Because of the continuing explorations of these natural gas wells, Port Said's western coastal region includes a lot of factories and plants which are based on natural gas processing plants. Recently, the huge ZOHR natural gas well had been explored and the decision was made to establish a new treatment plant in this region.

All over the world, coastal industrial projects such as power and natural gas processing plants may require the establishment of coastal structures (jetties, causeways, breakwaters, etc.). The new natural gas treatment plant is located directly on the Mediterranean coast and composed of different elements including flare stacks. Due to the fact of the small available area for project master plan, two flare stacks are planned to be constructed in the sea. The flare stacks and pipes racks will be connected to the shore by means of two causeways. Meanwhile, another marine structure, a temporary cofferdam, will be constructed for the purpose of installing gas pipelines under seabed extending from gas well located offshore to the onshore area where the new treatment plant exists and will be removed after finalizing pipelines installation. 
Coastal stretch studied was due to the sensibility of the existence of other factories nearby the new plant, the existence of new established protective groins to the east of the eastern causeway and the narrow width of the sandy beach that separates the new plant fence from the sea.

This research discusses the problem of constructing the previous mentioned marine structures and its impact on the shoreline evolution within the area of the project. Several research studies had been carried out on Nile Delta and the northern coast of Egypt, to assess impacts of coastal structures on the beach morphology and shoreline change, (Dabees and Kamphuis (1998) [4]; White and El Asmar (1999) [15]; Frihy et al. (2003)[10]; Ahmed (2006) [1]; Dewidar and Frihy (2010) [5]; Frihy and Debes (2011) [9]; Ahmed (2012) [2]; El Asmar et al. (2014)[6]; El-Sharnouby et al. (2015)[7]). Similar case studies research had been also carried out on shoreline change due to establishment of industrial projects along the northern coast of Egypt, (Kemp et al. (2007) [11]; Mahdy and Tolba (2012) [14]).

\section{STUDY AREA}

The study area, is located $12 \mathrm{~km}$ to the west of Port Said city at the northeastern coast of Egypt, faces the Mediterranean with an orientation approximately N54 ${ }^{\circ} \mathrm{W}$ and is essentially composed of sand stretches. The coordinates of the new project extend between $722250 \mathrm{E}$ to $724250 \mathrm{E}$ and $956000 \mathrm{~N}$ to $958000 \mathrm{~N}$. The morphology of the studied stretch is dominated by the proximity to El Manzala Lake and by the sand barrier that separates the lake from the sea.

The study area, extends from El Manasra village till the western inlet of El Manzala lake with a length of 5.5 $\mathrm{km}$ and includes three existing factories, the area of the new project and a new established groin filed ( 5 groins established on 2014), just to the west of the lake inlet. The northern border of the new treatment plant is the Mediterranean coast, the eastern border is UGDC gas treatment plant, the western border is the IPIC factory for the manufacture of pipes and the southern border is the international coastal road. Details of the study area are shown in Figure 1.

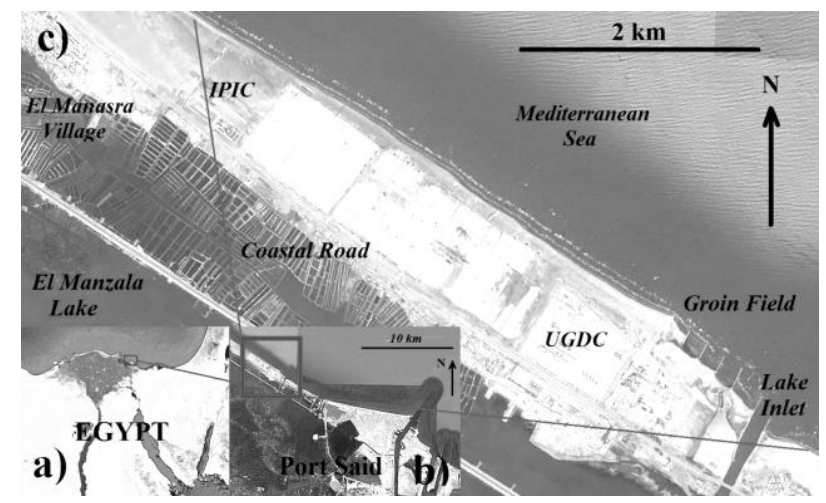

Figure 1: Location of the study area

The new project is a natural gas treatment plant extends $2723 \mathrm{~m}$ on Mediterranean Sea coast to the west of Port Said city. The study area comprises four marine structures, are shown in Figure 2, sequentially constructed as follows:

1. Existing Groin Field (2014): It consists of five groins established just to the west of El-Manzala Lake Inlet during the year 2014, by the Egyptian Shore Protection Authority (ESPA), to protect the Lake Inlet.

2. First Causeway (2016): The eastern causeway carrying the first flare stack. Its construction had been started on November 2016 and completely finished on February 2017.

3. Temporary Cofferdam (2016): Its construction had been started on December 2016 and completely finished on March 2017 (still in place till editing this paper and will be removed after finalizing the installation of gas pipelines).

4. Second Causeway (2018): The Western causeway carrying the second flare stack. Its construction had been started on January 2018 and still under construction till editing this paper.

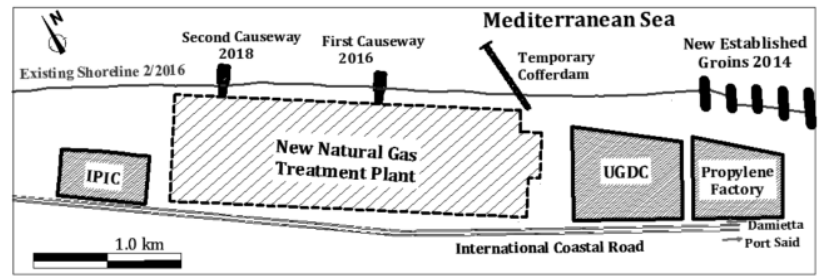

Figure 2: Marine structures within study area

\section{OBJECTIVES}

The main aims of our shoreline evolution investigation are to predict the impact of the coastal structures on shoreline evolution in the project area during the next few years, record (monitor) the impact of the current marine structures on shoreline evolution, verify shoreline evolution obtained by the monitoring process using satellite images, determine the locations of shoreline accretion and erosion, and put some recommendations for shoreline stability as a part of ICZM program for the study area.

\section{METHODOLOGY}

Three methods had been followed in the current research to achieve the aims of the thesis:

- Firstly, the numerical modeling: for studying the impact of the two causeways, constructed in 2016 and 2018 respectively, only without the existence of the temporary cofferdam.

- Then, the shoreline monitoring program: by applying seven surveying processes using total station device for representing the actual evolution of the shoreline under the impact of the causeways together with the temporary cofferdam for a period of 11 months.

- Finally, the satellite images verification: to verify shoreline evolution (due to the impact of all marine 
structures within the study area) obtained by the monitoring process, by a qualitative comparison between the shape of shoreline obtained at several surveying and the satellite images obtained using LAND VIWER.

Before starting any activities in the project area, a site visit had been carried out on 14/2/2016 to the study area. During the site visit, a complete shoreline surveying had been carried out with respect to the bench marks and control points of the project. The surveying process included also the positions of the new constructed 5 groins. The measured shoreline was connected to the fixed points coordinates and considered the initial shoreline before starting execution of the new project.

\subsection{Numerical Modeling}

A One-line Study was performed using LITPACK numerical model for coastal sediment transport and coastline development. One-line models calculate variations of the shoreline position $(\Delta Y)$ in time by solving the continuity equation for the total longshore transport $\left(\mathrm{Q}_{1}\right)$ along the shore-face, and by assuming that the coastal profile advances or retreats in response to shoreline accretion/erosion, while conserving its shape as shown in Figure 3.

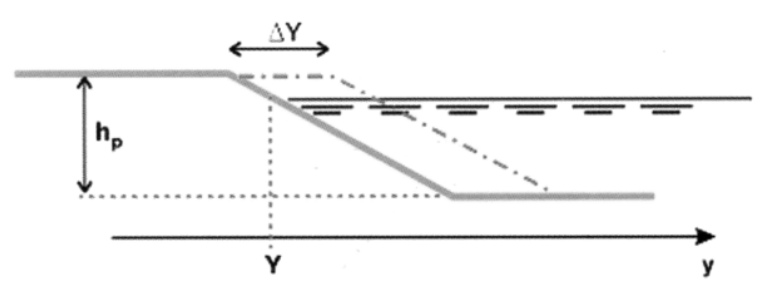

B

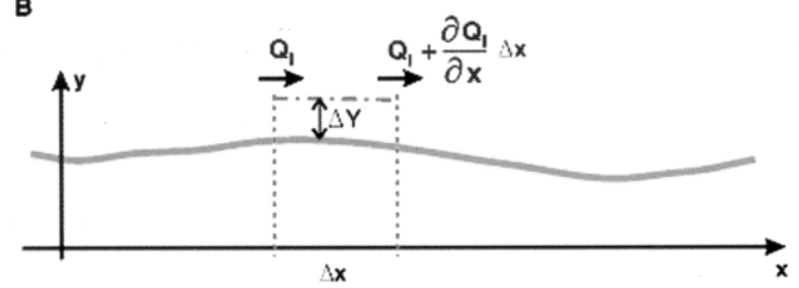

Figure 3: Principle of One-line shoreline evolution model

LITPACK is a professional engineering software package contains various modules that use a fully deterministic approach for the modeling of non-cohesive sediment transport in waves and currents, littoral drift, coastline evolution and profile development along quasiuniform beaches. LITLINE module was used to perform one-line study to predict shoreline evolution due to construction of both causeways through the evaluation of two scenarios (two stages):

- First stage: studying the effect of the first causeway only, constructed in 2016, on shoreline evolution for two years till 2018 and before constructing the second causeway.

- Second stage: including the effect of adding the second causeway in 2018 and simulating the shoreline evolution for 12 years from 2018 till 2030 for both causeways.

It should be mentioned here that the numerical work does not consider the existence of the temporary cofferdam because it was not planned from the beginning that the cofferdam will be executed before the second causeway. The early plan of construction considered that the temporary cofferdam shall be constructed after finishing the second flare stack causeway in 2018 and the decision of executing the cofferdam parallel to the first causeway in 2016 had been taken after finishing the numerical work.

\subsubsection{Data Collection}

In order to run one-line shoreline evolution model, many data are required to be defined such as history of shoreline, wave climate, and sediments properties.

○ Shoreline history

Shoreline history had been extracted from satellite images. The available shoreline satellite images dated 4/2009, 3/2011, 9/2011 and 8/2013 are shown in Figure 4 . The shoreline appears to be stable, except the Inlet of El Manzala Lake which subjected to obvious erosion. ESPA started to construct five groins in January 2014 to protect the Lake Inlet, and the construction process ended in November 2014. In order to obtain recent shoreline including the new groins, field survey had been carried out by the author on February 2016 using the same control point of the new plant. The measured and extracted shorelines are shown in Figure 5.

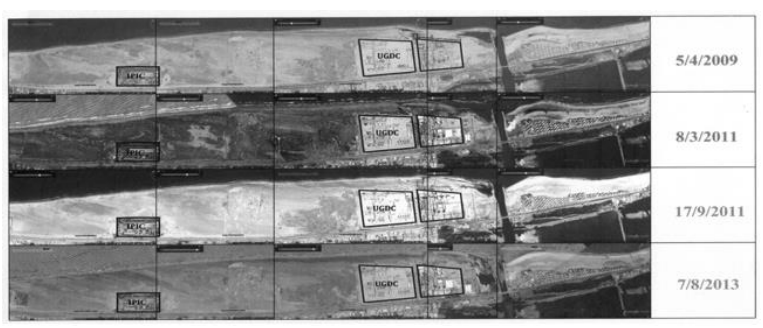

Figure 4: Extracted shoreline history using satellite images

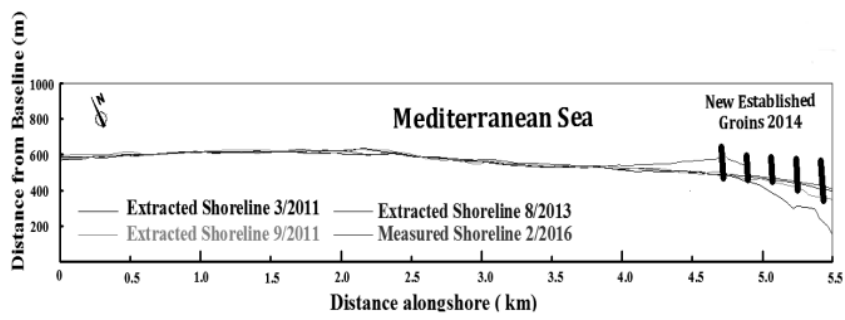

Figure 5: Measured shoreline 2/2016 and previous shorelines extracted from satellite images

- Wave climate 
Waves used for the current study are real measured time series waves measured by means of Port Said Dredging Company PSDC (1999/2000) during the phase of data collection for the purpose of constructing Port Said East Port. The wave data used for the study represents wave data for one complete year. The collected wave data was analyzed by Delft hydraulics and gave wave characteristics at 3 hour time step. The wave rose, which represents wave climate for Port Said region is shown in Figure 6.

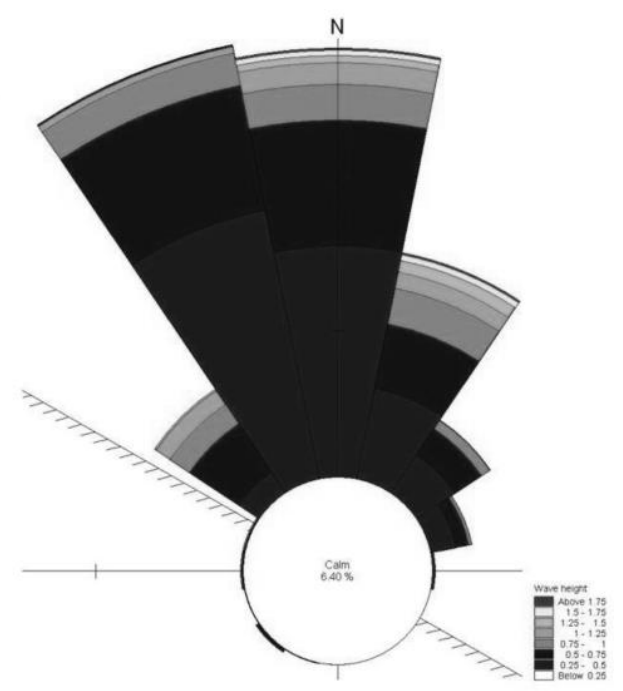

Figure 6: Wave Rose for Port Said region

- Sediments properties

Sediment properties have great influence on the accuracy of the numerical model. For such reason, two sediment samples had been collected from surf zone facing the location of the new project at different depths $1 \mathrm{~m}$ and $2 \mathrm{~m}$ respectively. Sieve analysis had been performed for both samples and the median grain size of the sediments was found to be $0.18 \mathrm{~mm}$. The results of sieve analysis of the two sediment samples are shown in Figures 7 and 8.

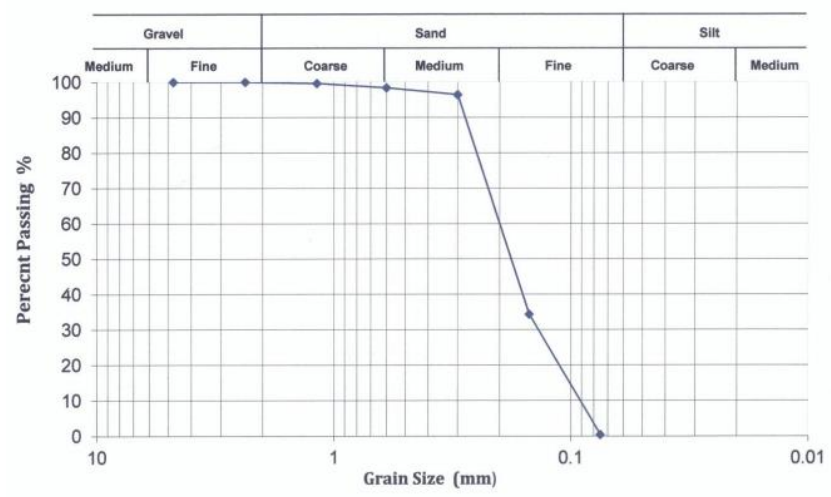

Figure 7: Sieve Analysis for Sample (A), (at Water depth $1.0 \mathrm{~m}$ )

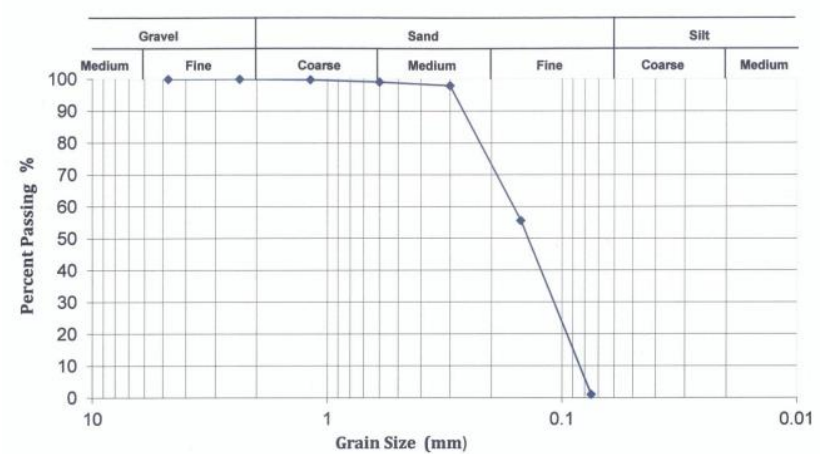

Figure 8: Sieve Analysis for Sample (B), (at Water depth $2.0 \mathrm{~m}$ )

\subsubsection{Model Setup}

In this study, LITLINE is based on one-line model. The governing equations are solved using finite difference approach and the software computes wave, shoaling, refraction, diffraction and the resulting sediment transport at each time step for each grid point. The model covers the area between the tidal Inlet of El Manzala Lake as the eastern boundary and extends to a distance of $1.5 \mathrm{~km}$ to the west side of IPIC plant as the western boundary, with entire length of the shoreline considered for the study equal to $5.5 \mathrm{~km}$ as shown in Figure 9.

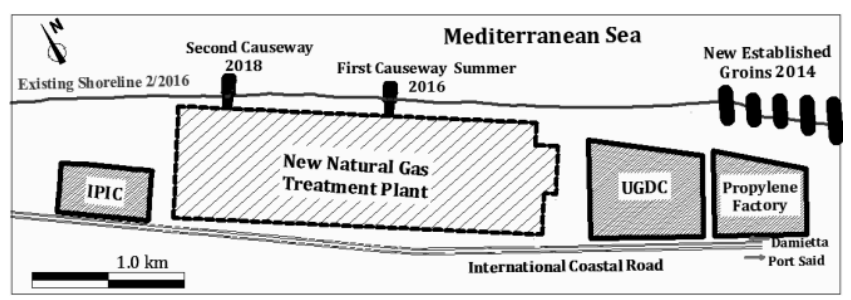

Figure 9: Boundaries of study area

The bathymetric and topographic data used to define the numerical spatial domain for modeling the study area were obtained by surveying several cross profiles through study area up to water depth of $-9.0 \mathrm{~m}$. Four different profiles were used along the shoreline which obtained using the full bathymetry carried out for the studied area on 2013 by ESPA. The depth of closure used in simulation is $7.81 \mathrm{~m}$ with characteristic sediment transport diameter, $\mathrm{d}_{50}$, of $0.18 \mathrm{~mm}$ for the entire study area. Wave climate with time step of 3 hours was used for the modeling. Finally, a regular grid for the spatial domain was obtained for modeling namely; shoreline was modeled by using 110 grid-cells, each $50 \mathrm{~m}$ long for the distance of $5.5 \mathrm{~km}$.

\subsubsection{Model Calibration}

Two phases had been undertaken for adjusting the model. The first phase was to calibrate the model for the period of 2011 to 2013, before the establishment of the five groins. For that purpose, the extracted shoreline of September 2011 was considered as the initial shoreline. The model was calibrated by comparing the modeled shoreline with the shoreline extracted from satellite 
image dated August 2013. The calibration results of the model are shown in Figure 10 and a relative error between modeled and extracted shoreline of value $0.181 \%$ was found on the easternmost end of the model due to tidal Inlet of El Manzala Lake. The results show that the modeled shoreline matches the measured one quite well, with only the small difference at the tidal Inlet.

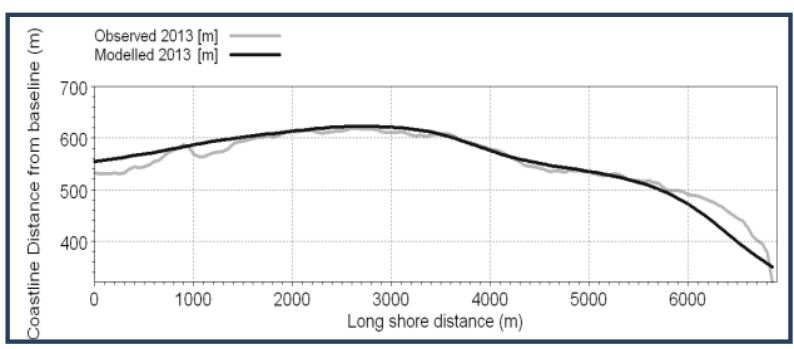

Figure 10: Model Calibration

\subsubsection{Model Validation}

The second phase was to verify the calibrated model, especially after the establishment of the five groins. For validation purpose, it was necessary to carry out a recent field survey for the stretch of the studied shoreline in the year 2016. The model was verified by comparing the modeled shoreline with the measured one. Validation process proved the validity of the model calibration process as the modeled and the measured shorelines have approximately the same trend with slight difference near the groin field. A validation comparison between the modeled and the measured shorelines for the year 2016 is shown in Figure 11.

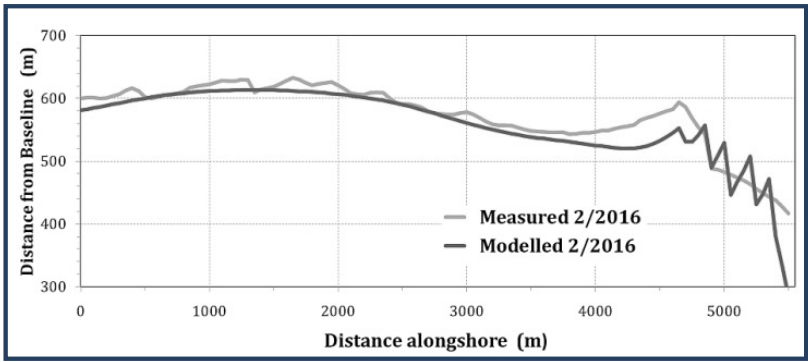

Figure 11: Model Validation

\subsection{Shoreline Monitoring Program}

A monitoring program for the shoreline had been planned to record the shoreline evolution periodically using total station device by applying seven surveying processes for a period of 11 months (from May 2017 to March 2018). The first six surveying processes had been carried out starting on May 2017 and ended on November 2017 in the existence of the first causeway and the temporary cofferdam only namely; before construction of the second causeway. The seven ${ }^{\text {th }}$ surveying carried out on March 2018 after starting construction of the second causeway including all marine structures within the study area.

\subsection{Satellite Images Verification}

This method is a qualitative one used to verify shoreline evolution obtained by the monitoring process. This will be performed by comparing each dated satellite image to the shoreline position obtained by surveying through the monitoring program. This method also presents the actual shoreline evolution of the study area under the impact of all marine structures within the study area. The satellite images for study area had been obtained at different dates from web site LAND VIEWER [13].

\section{RESULTS AND DISCUSSIONS}

\subsection{Results of Shoreline Evolution using Numerical Modeling}

As it is planned by the owner and designer, the construction process of the new gas treatment plant will be implemented through two phases. The first phase of construction process comprises the civil works of the plant and the first shore-connected flare stack during 2016 while, the second phase comprises the establishment of the second shore-connected flare stack which would be constructed in 2018, two years after constructing the first one. Model results represent the shoreline evolution after constructing both causeways connecting flare stacks to the shore.

The computed annual sediments transport was found to be $198 \times 10^{3} \mathrm{~m}^{3} /$ year towards west direction and $15 \times$ $10^{3} \mathrm{~m}^{3} /$ year towards east direction for the studied coastal area. Shoreline headway/ regression values and the acquired/ lost territory areas were obtained by comparing the evolved shorelines positions with respect to the initial shoreline of 2016. Control fixed points A to $\mathrm{H}$, located on the fences of the existing structures and shown in Figures 12 and 13, had been used as reference points facing the studied shoreline to facilitate the description of shoreline evolution.

\subsubsection{Shoreline evolution after construction of the first causeway}

Figure 12 shows the evolved shoreline of 2018, two years after the establishment of the first causeway connecting the flare stack to the shore, which is obviously affected by the existence of the causeway. During two years after constructing the first causeway, accretion happened and extended to the west of the causeway to a distance of $344 \mathrm{~m}$. This evolved shoreline also showed seaward maximum headway of $34.27 \mathrm{~m}$ recorded in front of point $\mathrm{D}$ and acquired territory of $4980 \mathrm{~m}^{2}$. However, to the east of the causeway, the entire shoreline stretch (2190 $\mathrm{m}$ long) between the causeway and the western groin had been retreated landward with values of $21.9,10.46,11.38$ and $13.09 \mathrm{~m}$ facing the points $\mathrm{E}, \mathrm{F}, \mathrm{G}$ and $\mathrm{H}$ respectively and lost territory of $35506 \mathrm{~m}^{2}$. The existence of the causeway had an impact on the slow sedimentation process inside the groin filed as the net acquired area inside the groin filed were $17660 \mathrm{~m}^{2}$ during the two years of study. The final 
shoreline distances to the reference points, 2 years after construction of the first causeway, are given in Table 1.

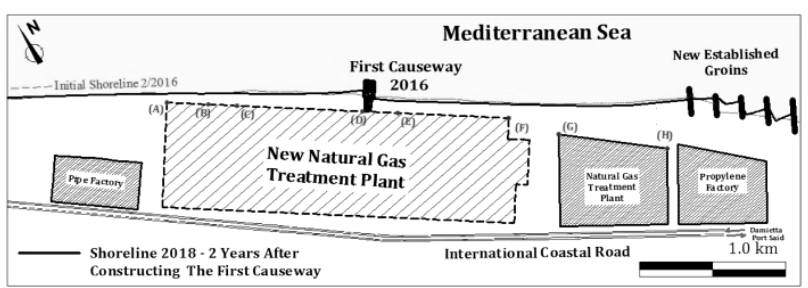

Figure 12: Evolved shoreline of 2018

\subsubsection{Shoreline evolution after construction of the second causeway}

The second shore-connected flare stack would have been established in 2018, at a distance $1060 \mathrm{~m}$ to the west of the first flare stack. For the purpose of analyzing and describing the evolved shoreline after construction of the second causeway, Figures 13 and 14 are introduced.

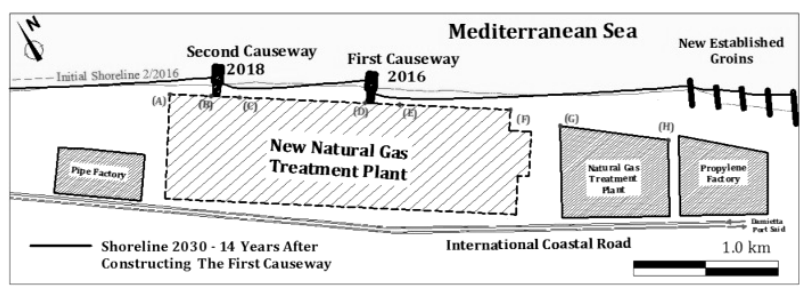

Figure 13: Evolved shoreline of 2030

Figure 14 shows the evolved shoreline after the establishment of the second causeway till 2030, 14 years after the establishment of the first causeway with respect to the existing structures using the control fixed points as mentioned before. While, Figures (14.a) to (14.d) show the evolution of studied shoreline over the years 2020, 2022, 2024 and 2030 respectively compared with the initial shoreline of February 2016. In Figure (14.a) the studied shoreline was divided into three zones, zone (A) located just to the west of the second causeway, zone (B) located between the two causeways and zone (C) located just to the east of the first causeway and extend up to the western groin.

The results of the evolved shoreline in zone (A) shown in Figure (14.b) showed continuous accretion process just to the west of the second causeway in which the lengths of accretion are 360, 447, 585 and $945 \mathrm{~m}$ in 2020, 2022, 2024 and 2030 respectively. Furthermore, the shoreline in this zone, facing point B in Figure 13, showed continuous seaward headway till 2030 with a value of $53.71 \mathrm{~m}$ during 14 years of simulation compared with shoreline 2016.

In zone (B) shown in Figure (14.c), erosion happened eastward of the second causeway and extended to the east direction with lengths of $635,636,638$ and $639 \mathrm{~m}$ in 2020, 2022, 2024 and 2030 respectively. The maximum shoreline regression value noticed is facing Point $\mathrm{C}$, shown in Figure 13, with a value of 33.56 m compared with the initial shoreline of 2016. The rest of zone (B) showed accretion towards east as the first causeway represents a boundary for littoral drift. The maximum shoreline seaward headway is noticed facing point $\mathrm{D}$, shown in Figure 13, with a value of $46.73 \mathrm{~m}$ in the year 2030 when compared with the initial shoreline of 2016.

In zone $(\mathrm{C})$, the entire regression of the shoreline happened in 2018 which is shown in Figure 12 had been changed. The evolved shoreline of this zone is shown in Figure (14.d) as the evolved shoreline showed erosion length to the east of the first causeway to a distance of $1150 \mathrm{~m}$ in the year 2030 with the maximum regression facing point $E$ with a value of $61.64 \mathrm{~m}$ when compared with the initial shoreline of 2016 . The rest of the evolved shoreline showed accretion extends to the western groin. The groin filed in 2030, shown in Figure (14.a), acquired a territory of $54200 \mathrm{~m}^{2}$ compared with the initial shoreline of 2016. The evolved shoreline positions after 2018 and its distances to the reference points are given in Table 1 . While, the acquired and the lost territory during simulation periods are given in Table 2 .

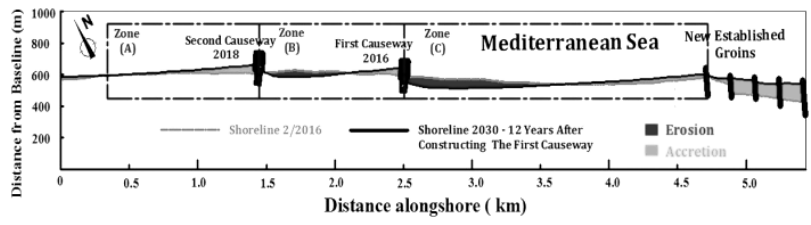

Figure 14.a: Zones of the studied shoreline

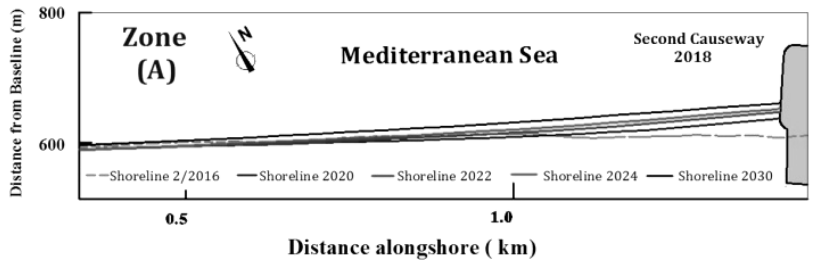

Figure 14.b: Shoreline evolution in zone A

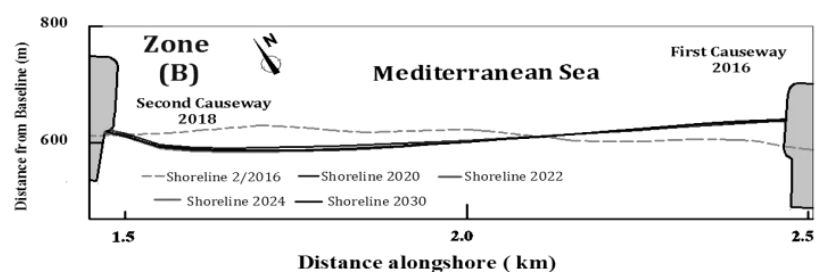

Figure 14.c: Shoreline evolution in zone B

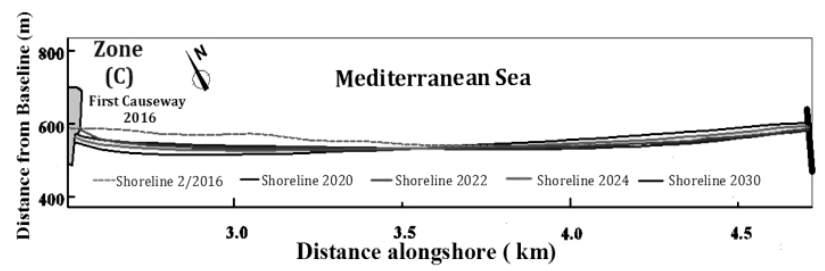

Figure 14.d: Shoreline evolution in zone C

Figure 14: Shoreline evolution during the 14 years after construction of the first causeway 
Table 1: Distances between evolved shoreline and reference points during simulation periods

\begin{tabular}{|c|c|c|c|c|c|c|c|}
\hline \multirow{2}{*}{$\begin{array}{c}\text { Reference } \\
\text { Points }\end{array}$} & \multicolumn{5}{|c|}{ Distance between shoreline and reference points (m) } & $\begin{array}{c}\text { Shoreline } \\
\text { (headway / } \\
\text { regression) } \\
\text { values in 14 } \\
\text { years (m) }\end{array}$ \\
\cline { 2 - 8 } & $\mathbf{2 0 1 6}$ & $\mathbf{2 0 1 8}$ & $\mathbf{2 0 2 0}$ & $\mathbf{2 0 2 2}$ & $\mathbf{2 0 2 4}$ & $\mathbf{2 0 3 0}$ & \begin{tabular}{c} 
(m) \\
\hline Point (A)
\end{tabular} \\
\hline Point (B) & 73.79 & 75.35 & 104.05 & 113.25 & 118.32 & 127.5 & 53.71 \\
\hline Point (C) & 96.51 & 83.54 & 66.92 & 61.98 & 60.86 & 62.95 & -33.56 \\
\hline Point (D) & 108.51 & 142.78 & 151.69 & 155.31 & 155.46 & 155.24 & 46.73 \\
\hline Point (E) & 105.51 & 83.61 & 73.75 & 69.28 & 59.05 & 43.87 & -61.64 \\
\hline Point (F) & 107.95 & 97.49 & 97.96 & 98.86 & 100.52 & 102.73 & -5.22 \\
\hline Point (G) & 209.13 & 197.75 & 201.75 & 204.89 & 210.03 & 217.45 & 8.32 \\
\hline Point (H) & 338.74 & 325.65 & 336.58 & 340.5 & 352.39 & 363.75 & 25.01 \\
\hline
\end{tabular}

Table 2: Acquired and lost territory during simulation periods

\begin{tabular}{|c|c|c|c|c|c|c|}
\hline \multirow{2}{*}{$\begin{array}{c}\text { Territory } \\
\text { Status }\end{array}$} & \multicolumn{6}{|c|}{ Area $\left(\mathbf{m}^{2}\right)$} \\
\cline { 2 - 7 } & $\mathbf{2 0 1 6}$ & $\mathbf{2 0 1 8}$ & $\mathbf{2 0 2 0}$ & $\mathbf{2 0 2 2}$ & $\mathbf{2 0 2 4}$ & $\mathbf{2 0 3 0}$ \\
\hline Area lost & 0 & 49127.1 & 50990.85 & 50499.6 & 55064.23 & 61598.48 \\
\hline $\begin{array}{c}\text { Area } \\
\text { acquired }\end{array}$ & 0 & 31360.34 & 56488.85 & 73229.68 & 81575.14 & 104937.65 \\
\hline
\end{tabular}

\subsection{Results of Shoreline Evolution using Monitoring Program}

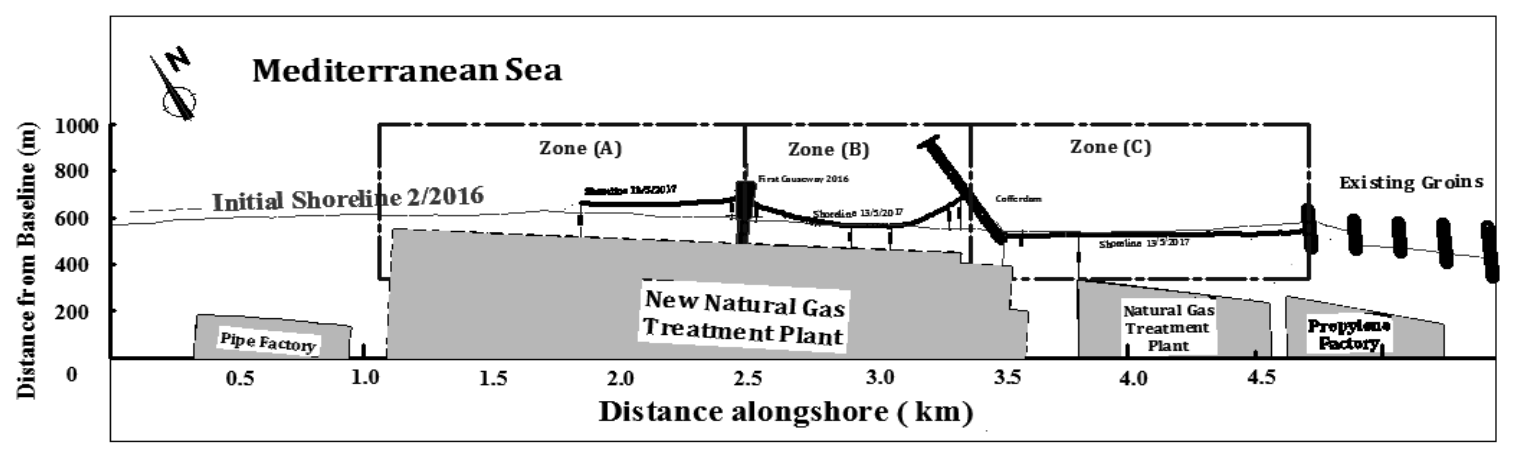

Figure 15: Position of shoreline on 13/5/2017, survey No.1

This stage presents the results of shoreline evolution obtained using periodical surveying (monitoring program). The results represent seven surveying processes started on May 2017 till March 2018. Figure 15 illustrates the results of the first survey carried out on $13 / 5 / 2018$. In this figure, the results were plotted on the same figure together with the base shoreline of 2/2016 for the purpose of presenting the shoreline evolution versus time. The studied shoreline stretch was divided into three zones ( $\mathrm{A}, \mathrm{B}$ and $\mathrm{C}$ ) exactly as followed in presenting the results of the numerical study. Zone (A), represents the distance extends from the start point of the plant west until the centerline of the first causeway to the east. Zone (B) represents the mid distance of the shoreline which extends from the centerline of the first causeway to the east direction till the cofferdam. Finally Zone (C), represents the third zone of the shoreline extends from the cofferdam to the east direction till the groin field. The followings will present the evolution of the shoreline in every zone versus time. 


\subsubsection{Results of shoreline evolution in zone (A)}

Survey No.1 (13/5/2017): In zone (A), the shoreline showed accretion and shoreline moved seaward for the entire surveyed stretch. The maximum headway distance recorded for the shoreline was $87.65 \mathrm{~m}$ seaward, just to the west of the causeway, with respect to the initial shoreline of $2 / 2016$. The average distance between the shoreline and the plant fence was $143.68 \mathrm{~m}$, (see Figure 16.a).

Survey No.2 (9/7/2017): The shoreline showed accretion and shoreline moved seaward for the entire surveyed stretch. The maximum headway distance recorded for the shoreline was $98.71 \mathrm{~m}$ seaward, just to the west of the causeway, with respect to the initial shoreline of $2 / 2016$. The average distance between the shoreline and the plant fence was $138.68 \mathrm{~m}$, (see Figure 16.b).

Survey No.3 (12/8/2017): The shoreline showed accretion and shoreline moved seaward for the entire surveyed stretch. The maximum headway distance recorded for the shoreline was $121.58 \mathrm{~m}$ seaward, just to the west of the causeway, with respect to the initial shoreline of $2 / 2016$. The average distance between the shoreline and the plant fence was $139.51 \mathrm{~m}$, (see Figure 16.c).

Survey No.4 (19/9/2017): The shoreline showed accretion and shoreline still in continuous movement seaward just to the west of the causeway. The maximum headway distance recorded for the shoreline was $135 \mathrm{~m}$ seaward, west of the causeway, with respect to the initial shoreline of $2 / 2016$. The average distance between the shoreline and the plant fence was $136.32 \mathrm{~m}$, (see Figure 16.d).

Survey No.5 (18/10/2017): The shoreline measured on 18/10/2017 had no significant changes when compared with shoreline of survey No.4 dated 19/9/2017. The maximum headway distance recorded for the shoreline was $132 \mathrm{~m}$ seaward, west of the causeway, with respect to the initial shoreline of $2 / 2016$, (see Figure 16.e).

Survey No.6 (26/11/2017): The shoreline measured on 26/11/2017 had moved landward when compared with shoreline of survey No.5 dated 18/10/2017. The distance recorded for the shoreline position measured till plant fence was $225.03 \mathrm{~m}$ west of the causeway, (see Figure 16.f). It should be mentioned here that construction work of the second causeway has started during January 2018. It is expected that the shoreline will record some changes during the period till the next survey.

Survey No.7 (15/3/2018): The construction works in the second causeway (western causeway) is in progress. The shoreline in zone (A) had new evolution in which the shoreline west of the second causeway showed accretion with movement seaward with a distance of $84.46 \mathrm{~m}$. while east of the second causeway, the stretch between both causeways showed accretion just beside each causeway and shoreline retreat in the middle of the stretch when compared with the previous surveyed positions, (see Figure 16.g).

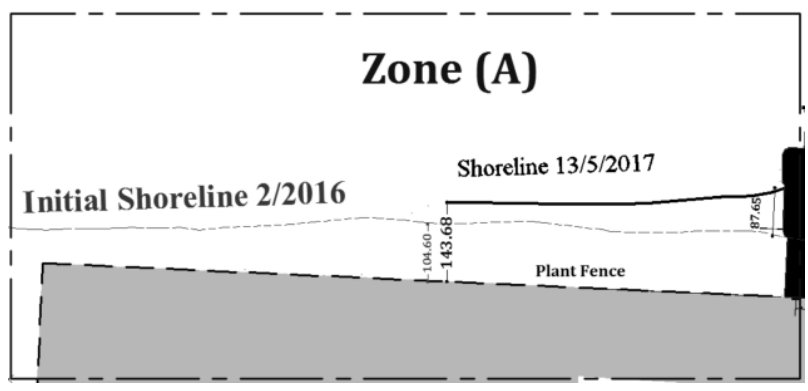

Figure 16.a: Survey No.1 - 13/5/2017

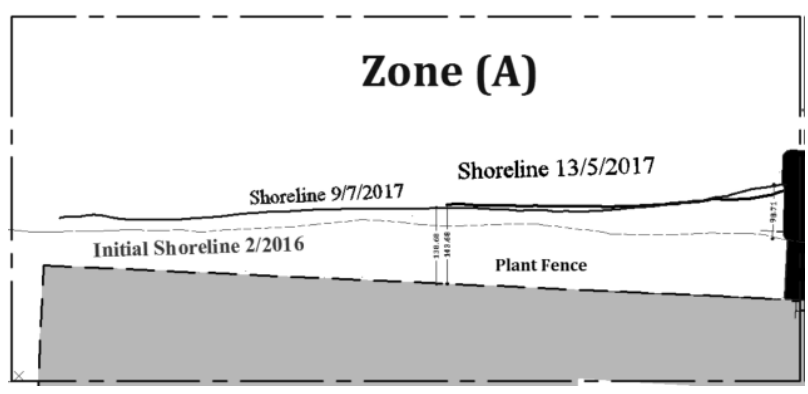

Figure 16.b: Survey No.2 - 9/7/2017

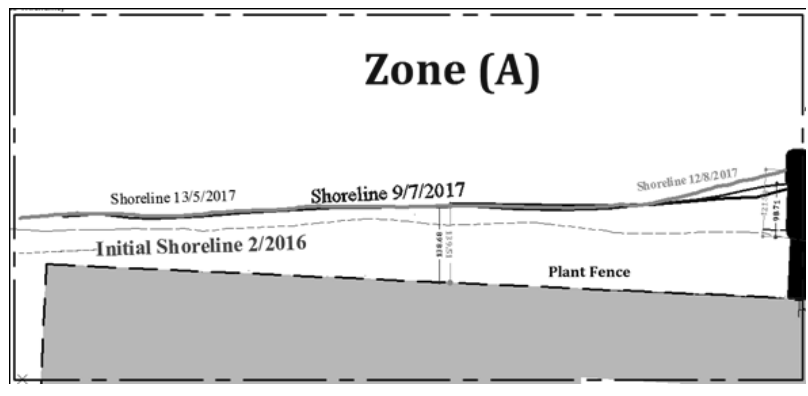

Figure 16.c: Survey No.3 - 12/8/2017

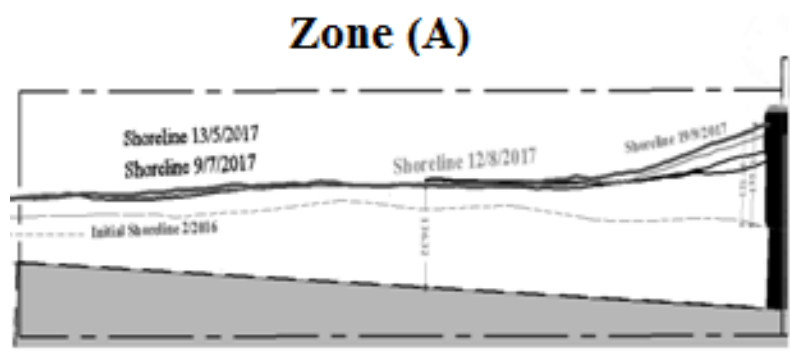

Figure 16.d: Survey No.4 - 19/9/2017

\section{Zone (A)}

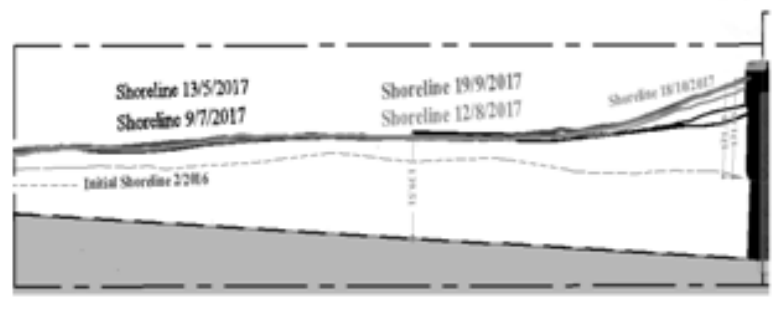

Figure 16.e: Survey No.5 - 18/10/2017 


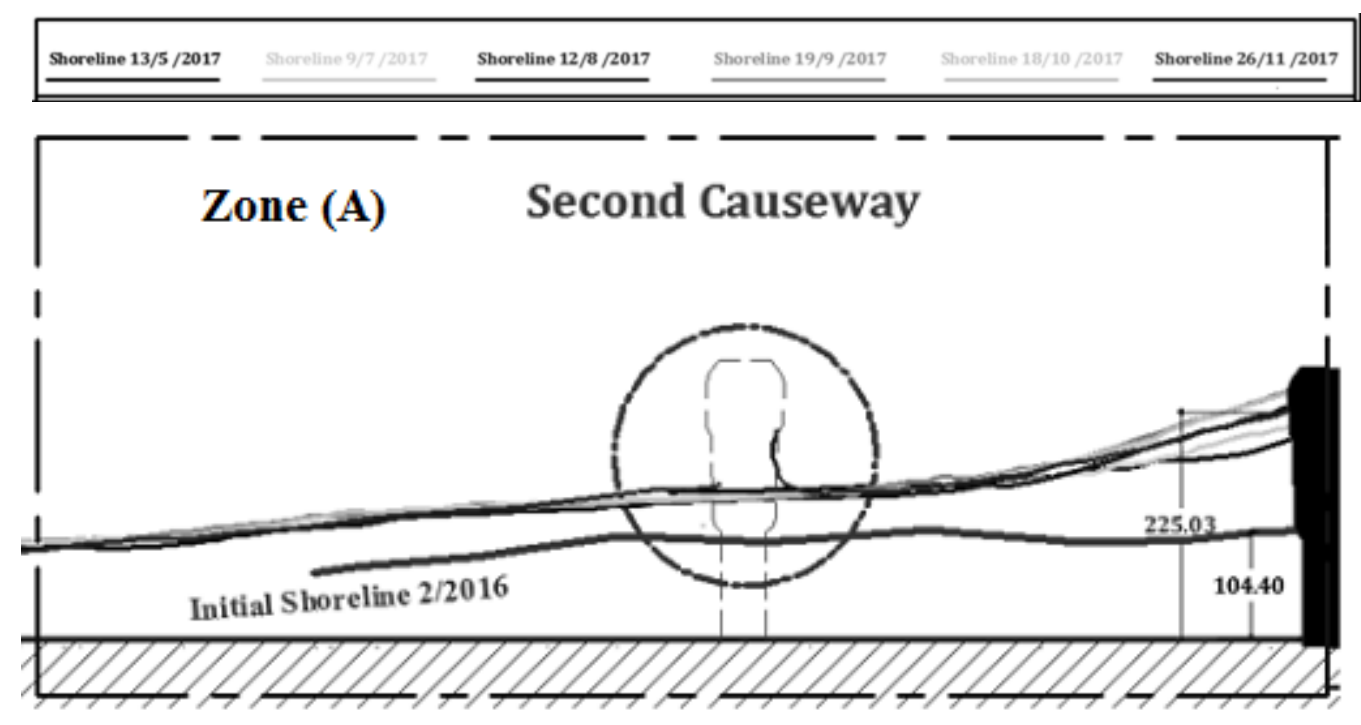

Figure 16.f: Survey No.6 - 26/11/2017

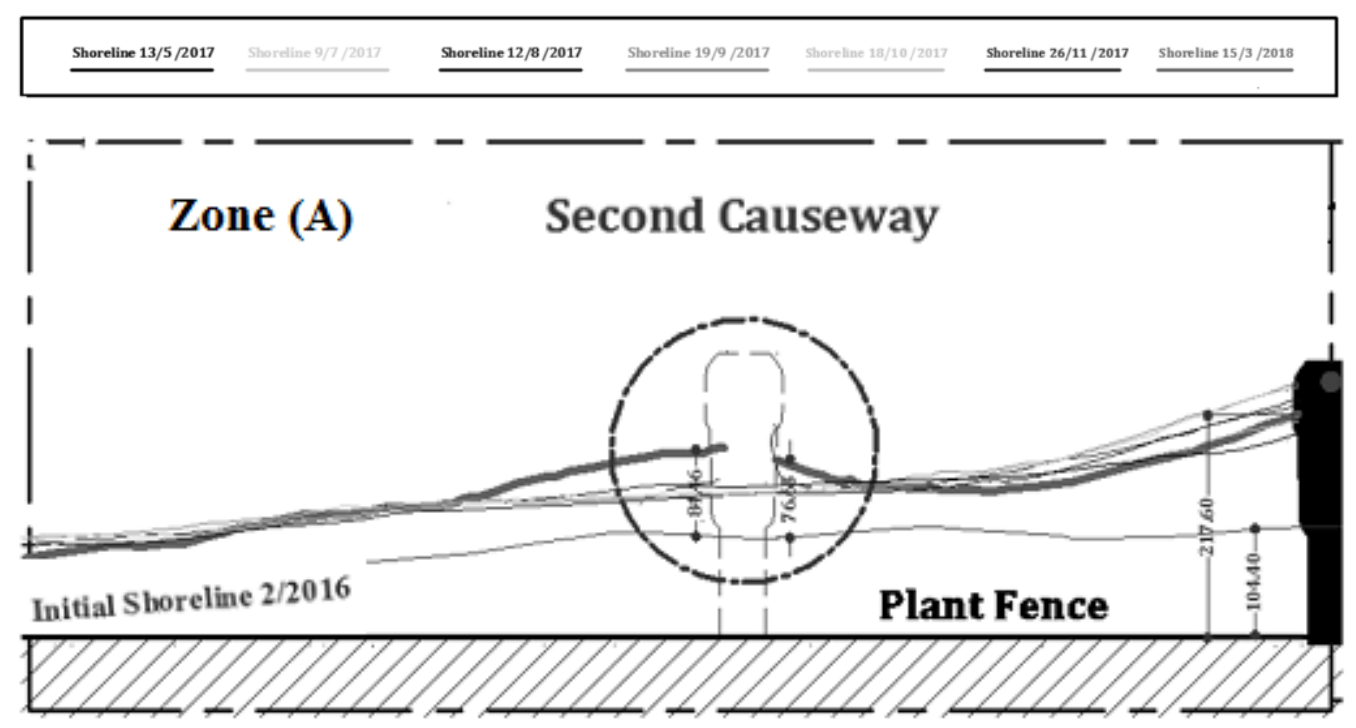

Figure 16.g: Survey No.7 - 15/3/2018

Figure 16: Shoreline evolutions in zone (A), results of monitoring

\subsubsection{Results of shoreline evolution in zone (B)}

Survey No.1 (13/5/2017): In zone (B), the shoreline showed accretion beside both marine structures. The shoreline moved seaward with distance of $75.90 \mathrm{~m}$ just to the east of the causeway with respect to the initial shoreline, while the shoreline showed greater distance seaward with value of $130.91 \mathrm{~m}$ seaward just to the west of the cofferdam. In the mid distance, the shoreline showed recession and the net distance between the shoreline and plant fence showed a value of $97.71 \mathrm{~m}$, (see Figure 17.a).

Survey No.2 (9/7/2017): The shoreline showed accretion beside both marine structures. The shoreline moved seaward with distance of $64.12 \mathrm{~m}$ just to the east of the causeway with respect to the initial shoreline, while the shoreline showed greater distance seaward with value of $142.87 \mathrm{~m}$ seaward just to the west of the cofferdam. In the mid distance, the shoreline showed recession and the net distance between the shoreline and plant fence showed a value of $94.33 \mathrm{~m}$, (see Figure 17.b).

Survey No.3 (12/8/2017): The shoreline showed accretion beside both marine structures. The shoreline moved seaward with distance of $47.19 \mathrm{~m}$ just to the east of the causeway with respect to the initial shoreline, while the shoreline showed greater distance seaward with value of 151.21 seaward just to the west of the cofferdam. In the mid distance, the shoreline showed recession and the net distance between the shoreline and plant fence showed a value of $84.44 \mathrm{~m}$, (see Figure 17.c).

Survey No.4 (19/9/2017): The shoreline still shows accretion beside both marine structures (Causeway and cofferdam). The shoreline of 19/9/2017 showed a shape of Small Island just to the east of the causeway as the sediments began to transport from the west side around the tip of the causeway. Furthermore, the shoreline just to the west of cofferdam showed greater distance 
seaward with value of $157.98 \mathrm{~m}$. In the mid distance, the shoreline showed distance between the shoreline and plant fence showed a value of $84.44 \mathrm{~m}$, (see Figure 17.d).

Survey No.5 (18/10/2017): The shoreline is stable when compared with the shoreline of September 2017. It is noticed that sediment accumulation just to the east of the causeway had moved landward. The rest of the stretch of zone (B) showed no significant change with respect to the results of the previous survey No.4 dated 19/9/2017, (see Figure 17.e).

Survey No.6 (26/11/2017): The shoreline recorded seaward movement when compared with the shoreline of October 2017 (Survey No.5). It is noticed that sediment accumulation just to the east of causeway had moved seaward. At the middle of the stretch of zone (B), the current shoreline advanced seaward with distance of almost $10 \mathrm{~m}$ as shown in Figure (17.f), when compared with the previous survey No.5 dated 18/10/2017. For the eastern portion of zone (B), the shoreline still advances seaward recording a distance of $227.54 \mathrm{~m}$ till the plant fence.

Survey No.7 (15/3/2018): The temporary cofferdam had been shifted to the west for the purpose of installing the rest of pipelines connecting the well to the processing plant. The shoreline had the shape of the previous surveying except that more accumulations appeared just to the west of the cofferdam. The minimum distance recorded between the current shoreline and plant fence is $91.81 \mathrm{~m}$, (see Figure 17.g).

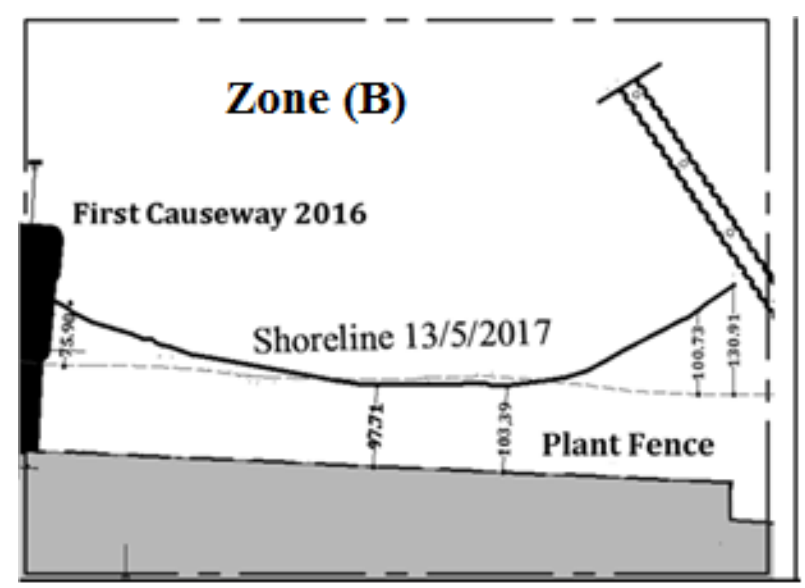

Figure 17.a: Survey No.1 - 13/5/2017

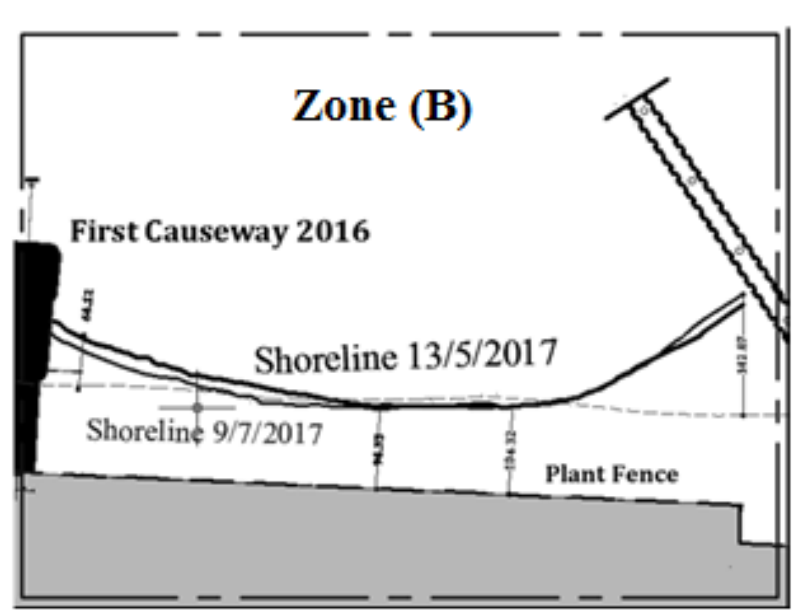

Figure 17.b: Survey No.2 - 9/7/2017

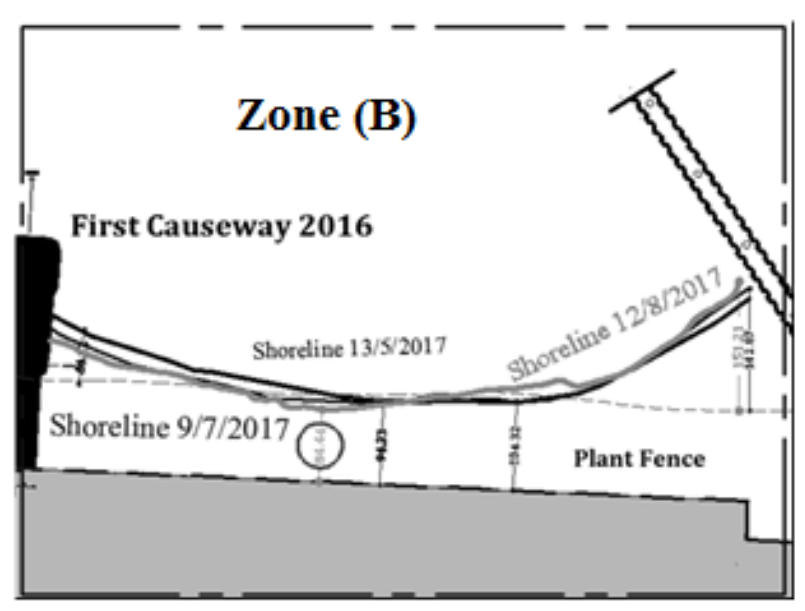

Figure 17.c: Survey No.3 - 12/8/2017

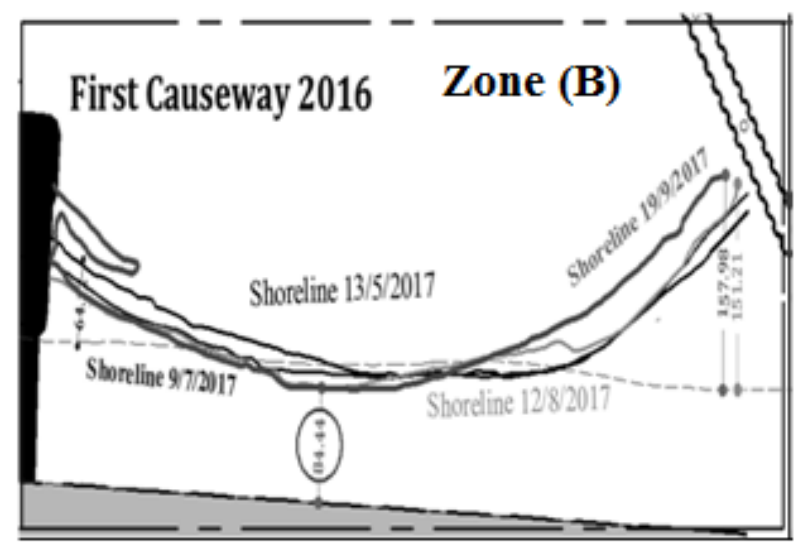

Figure 17.d: Survey No.4 - 19/9/2017 


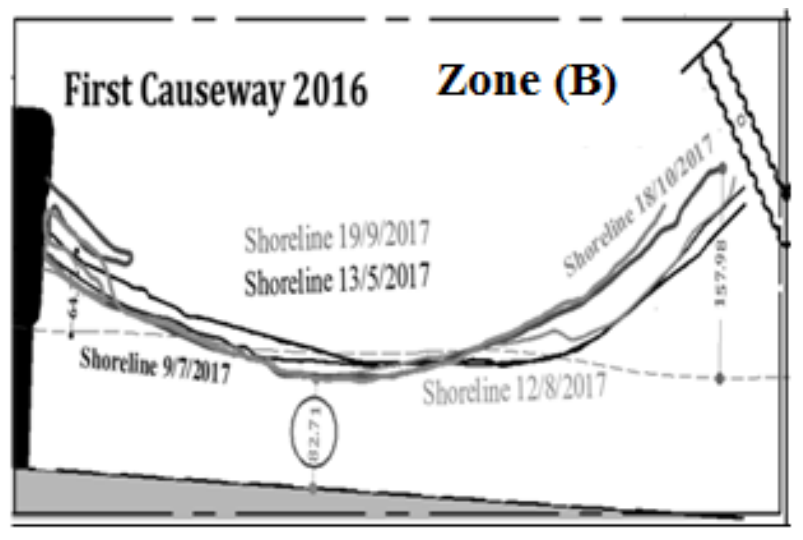

Figure 17.e: Survey No.5 - 18/10/2017

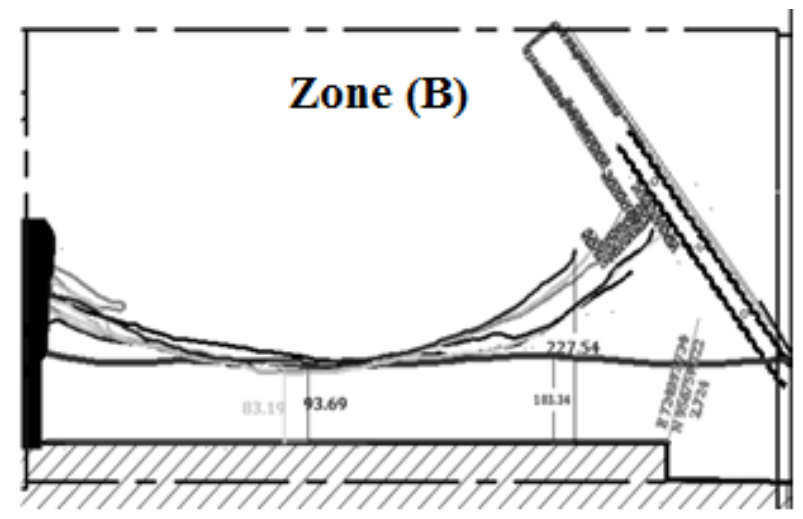

Figure 17.f: Survey No.6 - 26/11/2017

\section{Shoreline 13/5/2017 Shoreline $9 / 7 / 2017 \quad$ Shoreline 12/8/2017 Shoreline 19/9/2017 Shoreline 18/10/2017 Shoreline 26/11/2017 Shoreline 15/3/2018}

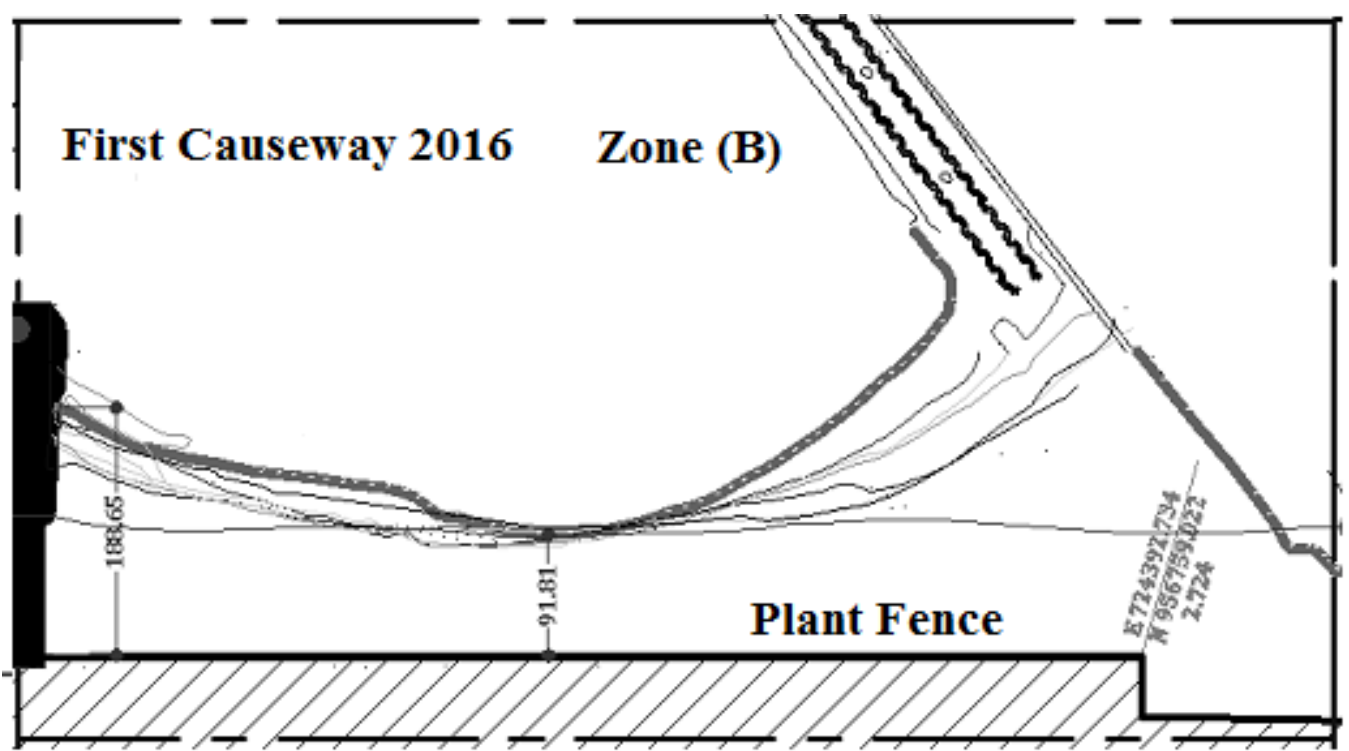

Figure 17.g: Survey No.7 - 15/3/2018

Figure 17: Shoreline evolutions in zone (B), results of monitoring

\subsubsection{Results of shoreline evolution in zone (C)}

Survey No.1 (13/5/2017): In zone (C), the entire stretch of this zone showed recession and retreat of the shoreline. The eroded distance just to the east of the cofferdam showed a distance of $24.57 \mathrm{~m}$ with respect to the initial shoreline. The minimum distance between the recent shoreline and the UGDC plant is $196.37 \mathrm{~m}$, (see Figure 18.a).

Survey No.2 (9/7/2017): The entire stretch of zone (C) showed recession and retreat of the shoreline. The eroded distance just to the east of the cofferdam is 40.1 $\mathrm{m}$ with respect to the initial shoreline. The minimum distance between the recent shoreline and the UGDC plant is $185.62 \mathrm{~m}$, (see Figure 18.b).

Survey No.3 (12/8/2017): The entire stretch of this zone showed recession and retreat of the shoreline. The eroded distance just to the east of the cofferdam increased during one month to be $44.1 \mathrm{~m}$ instead of 40.1 $\mathrm{m}$ recorded in July 2017, with respect to the initial shoreline. The minimum distance between the recent shoreline and the UGDC plant is $176.82 \mathrm{~m}$ instead of being $185.62 \mathrm{~m}$ on 9/7/2017, (see Figure 18.c).

Survey No.4 (19/9/2017): The stretch just to the east of the cofferdam showed small recession and retreat of the shoreline. The rest of shoreline of this zone showed small variations when compared with previous surveyed shorelines, (see Figure 18.d).

Survey No.5 (18/10/2017): The stretch just to the east of the cofferdam showed small recession and retreat of the shoreline. The rest of shoreline of this zone showed small variations when compared with previous surveyed shorelines No.3 and No.4, (see Figure 18.e).

Survey No.6 (26/11/2017): The stretch just to the east of the cofferdam showed small recession and retreat of the shoreline. The rest of shoreline of this zone showed small variations when compared with previous surveyed shorelines No.4 and No.5, (see Figure 18.f). 
Survey No.7 (15/3/2018): The shoreline retreated landward during this survey. The minimum distance between the recent shoreline and the UGDC plant is $164.1 \mathrm{~m}$ instead of being $187.10 \mathrm{~m}$ on $26 / 11 / 2017$, (see Figure 18.g).

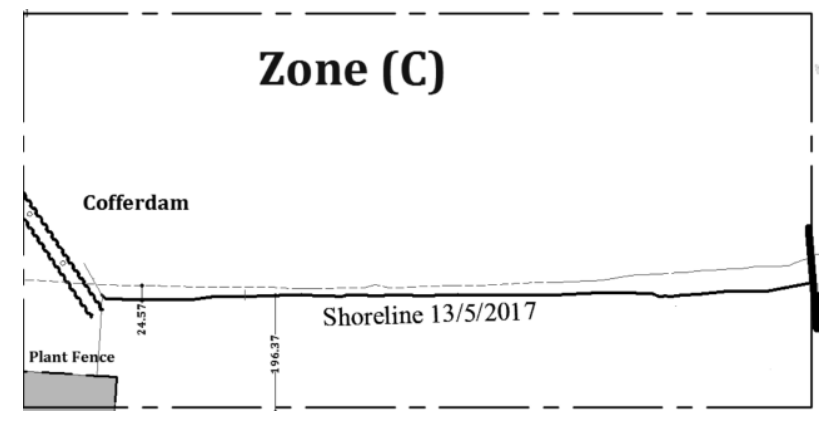

Figure 18.a: Survey No.1 - 13/5/2017

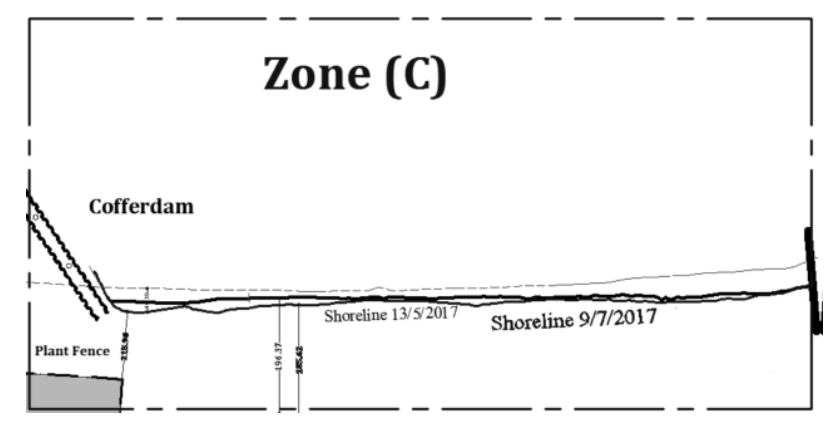

Figure 18.b: Survey No.2 - 9/7/2017

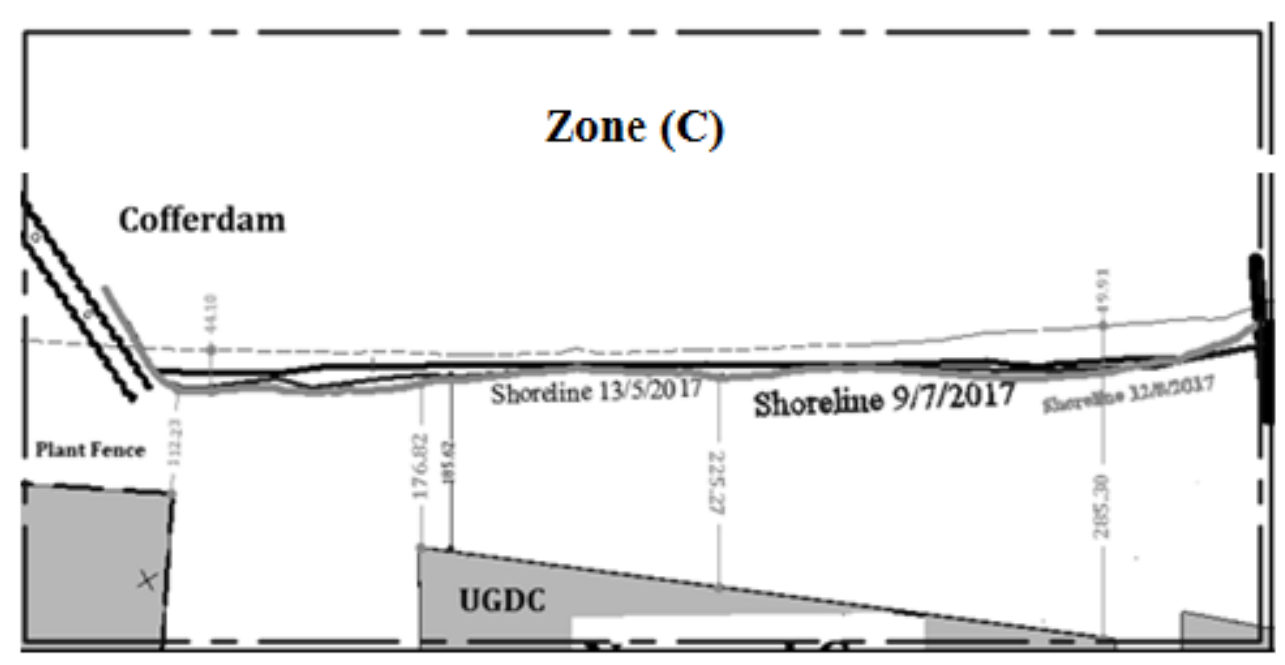

Figure 18.c: Survey No.3 - 12/8/2017

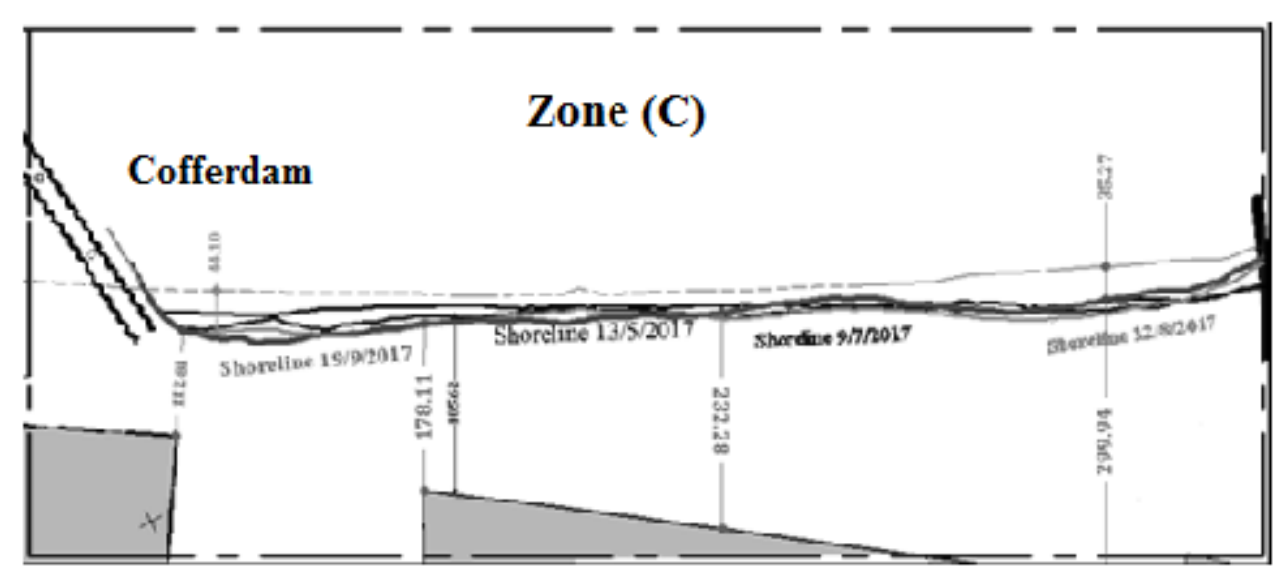

Figure 18.d: Survey No.4 - 19/9/2017 


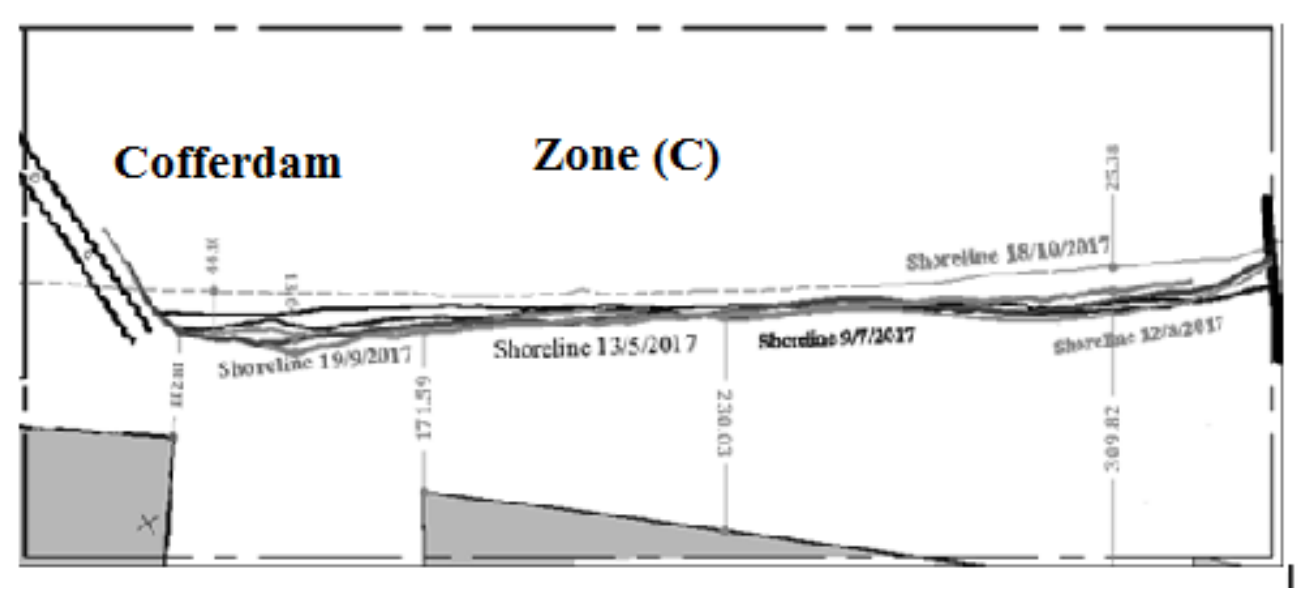

Figure 18.e: Survey No.5 - 18/10/2017

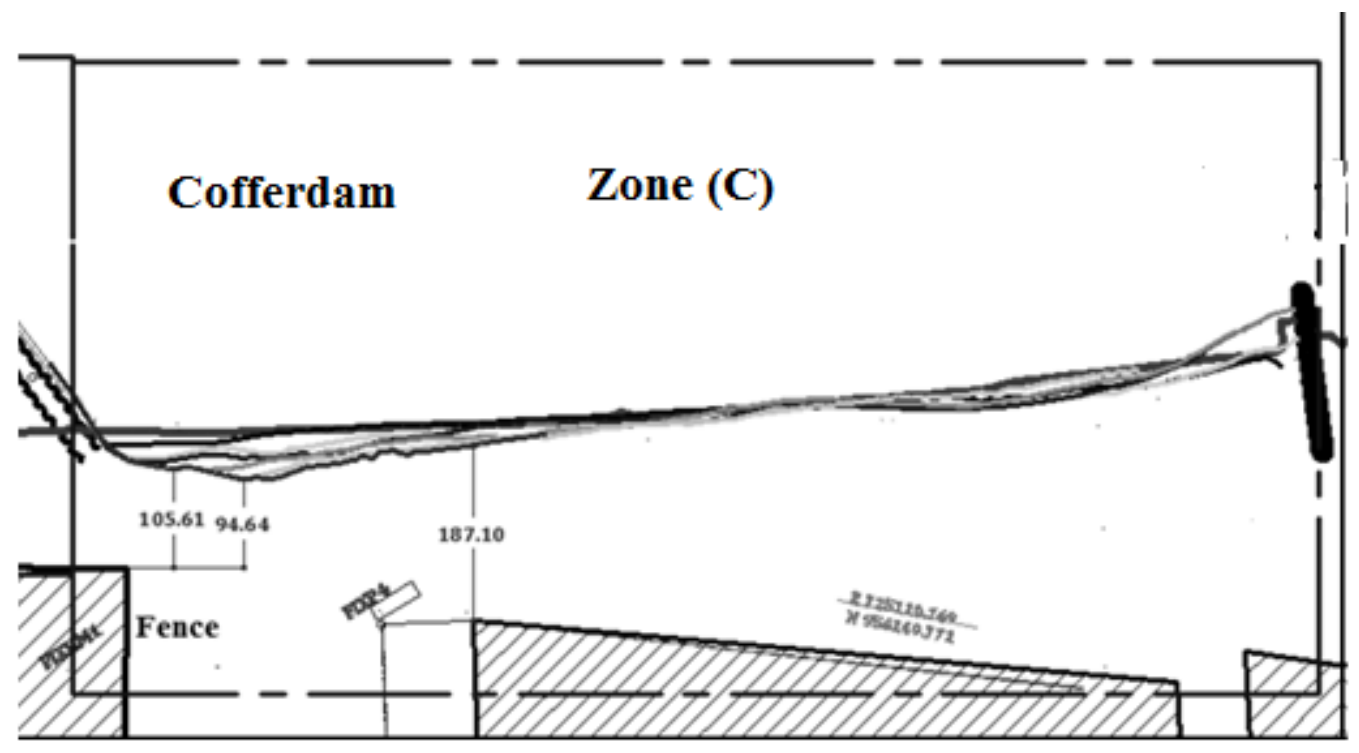

Figure 18.f: Survey No.6 - 26/11/2017

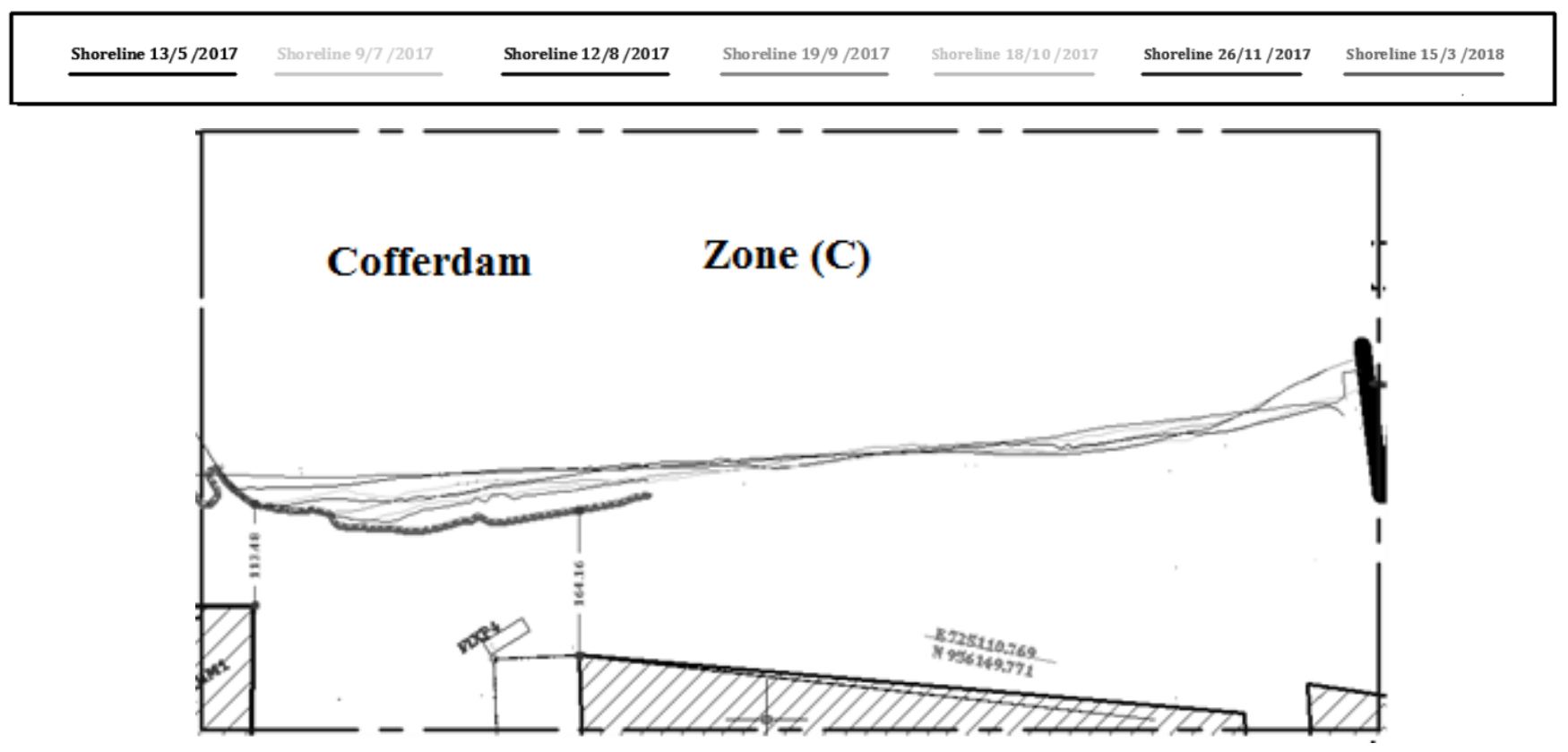

Figure 18.g: Survey No.7 - 15/3/2018

Figure 18: Shoreline evolutions in zone $(C)$, results of monitoring 


\subsection{Results of Shoreline Evolution using Satellite Images}

The third method used for investigating shoreline evolution in the study area had been done using satellite images. This method may be considered as a verification method for checking the shoreline evolution obtained using shoreline monitoring method. This could be done by a qualitative comparison between the shape of shoreline obtained at several surveying and the satellite images obtained using LAND VIWER.

In other words, this method is a qualitative one used to verify shoreline evolution obtained by the monitoring process. This will be performed by comparing each dated satellite image to the shoreline position obtained by surveying through the monitoring program.
The satellite images could be obtained at any date from web site LAND VIEWER (mentioned previously in section 4.3). This method also presents the actual shoreline evolution of the study area under the impact of all marine structures within the study area as given in Figures 19 to 22 .

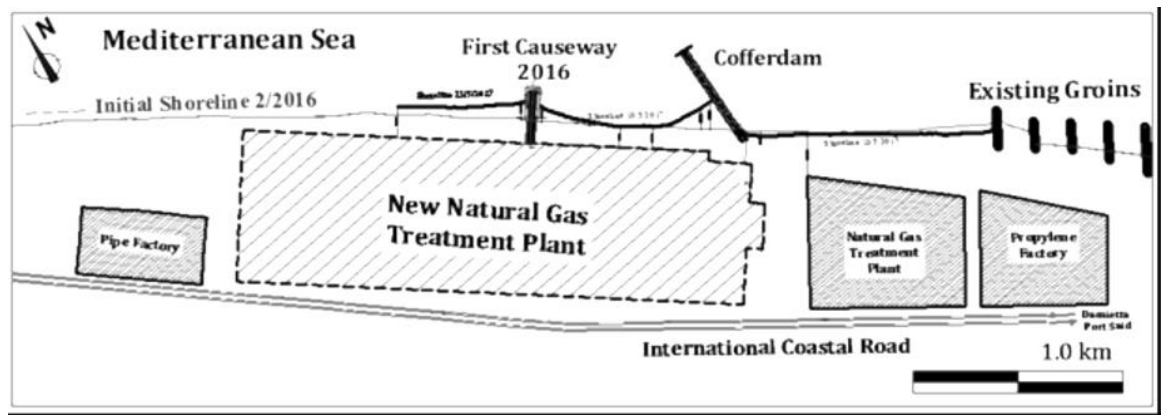

Figure 19.a: Position of shoreline on 13/5/2017, survey No.1

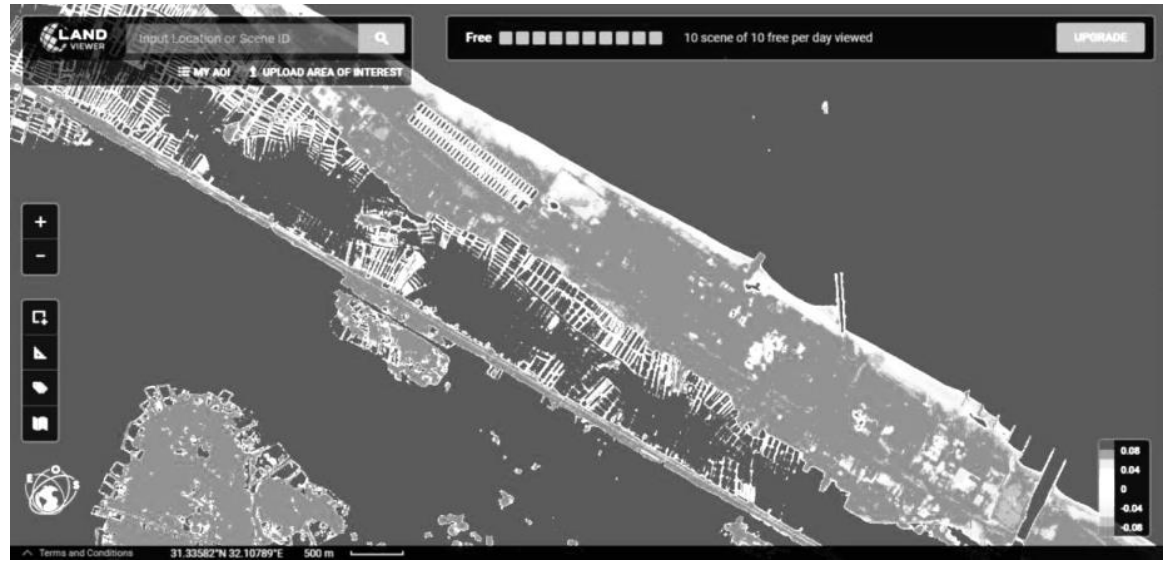

Figure 19.b: Satellite image for the study area dated 4/5/2017

Figure 19: Verification of shoreline evolution: (a) surveyed shoreline, (b) satellite image for the shoreline

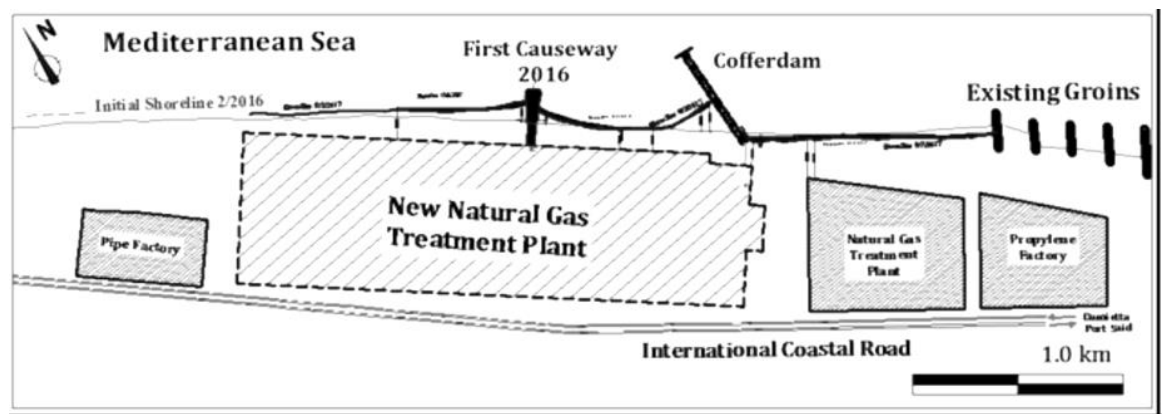

Figure 20.a: Position of shoreline on 9/7/2017, survey No.2 


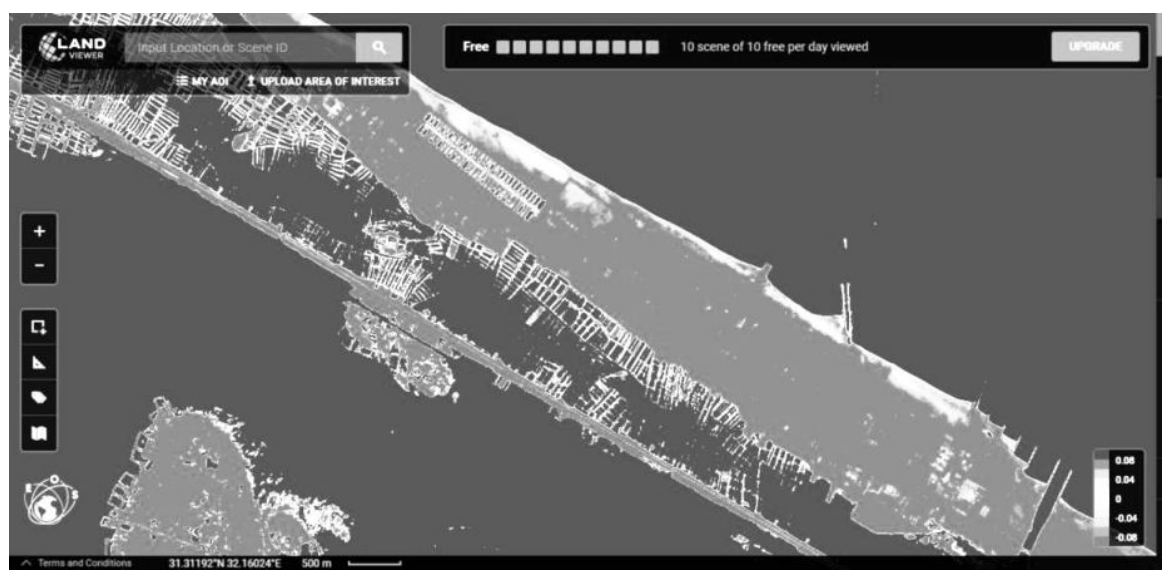

Figure 20.b: Satellite image for the study area dated 3/7/2017

Figure 20: Verification of shoreline evolution: (a) surveyed shoreline, (b) satellite image for the shoreline

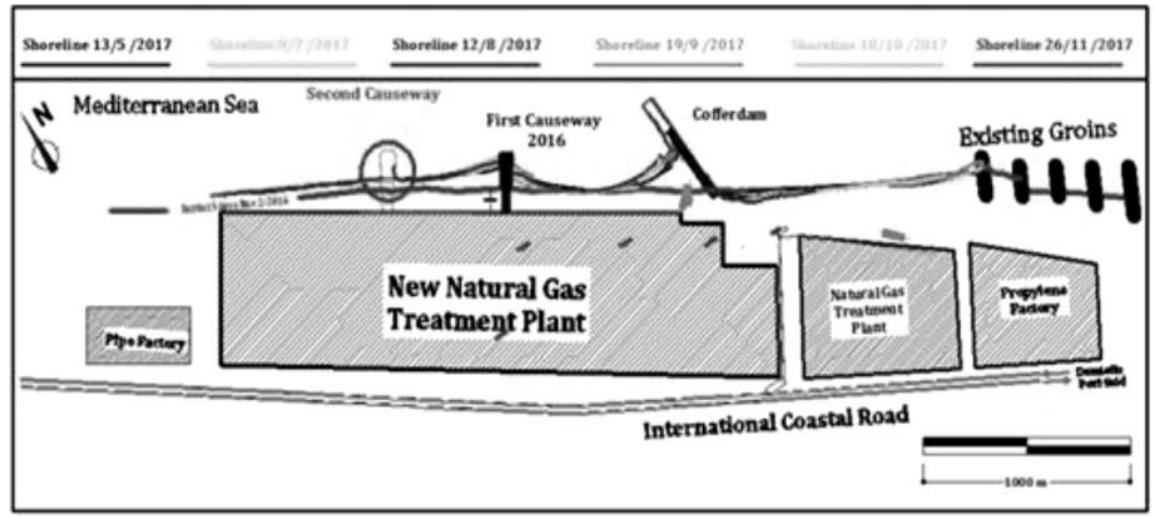

Figure 21.a: Position of shoreline on 26/11/2017, survey No.6

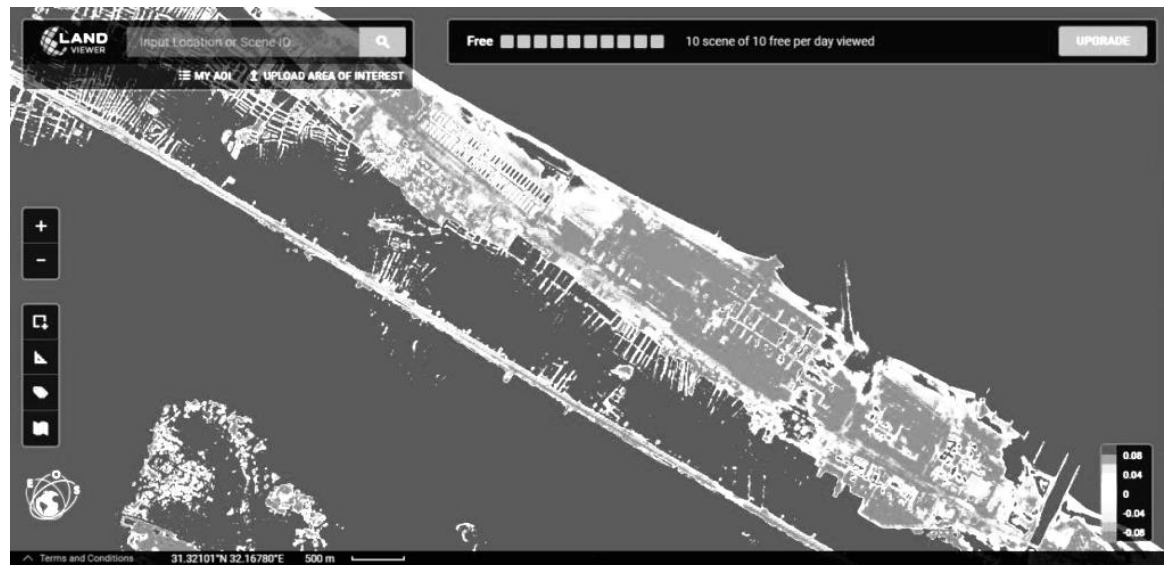

Figure 21.b: Satellite image for the study area dated 15/12/2017

Figure 21: Verification of shoreline evolution: (a) surveyed shoreline, (b) satellite image for the shoreline 


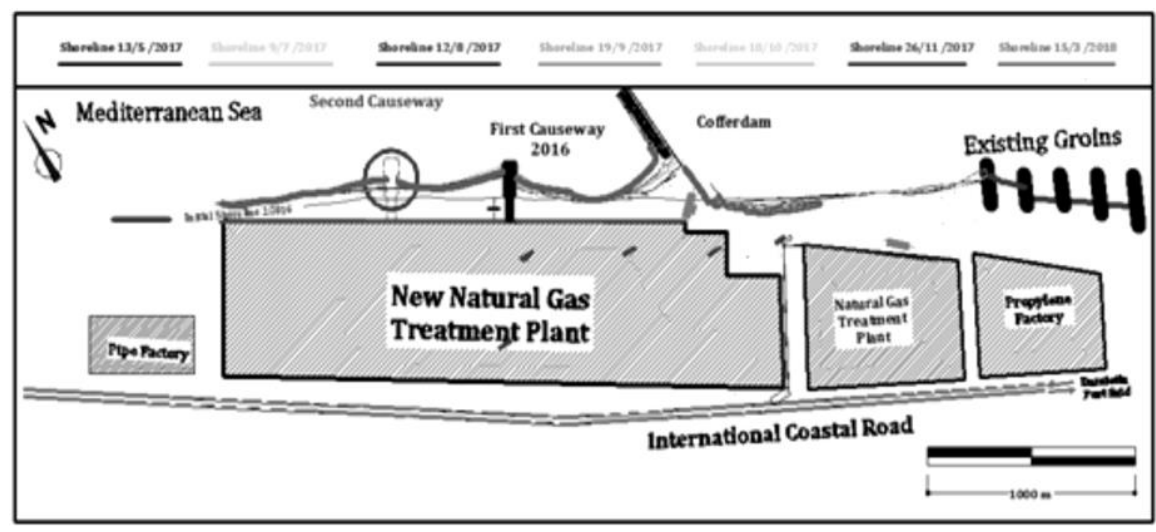

Figure 22.a: Position of shoreline on 15/3/2018, survey No.7

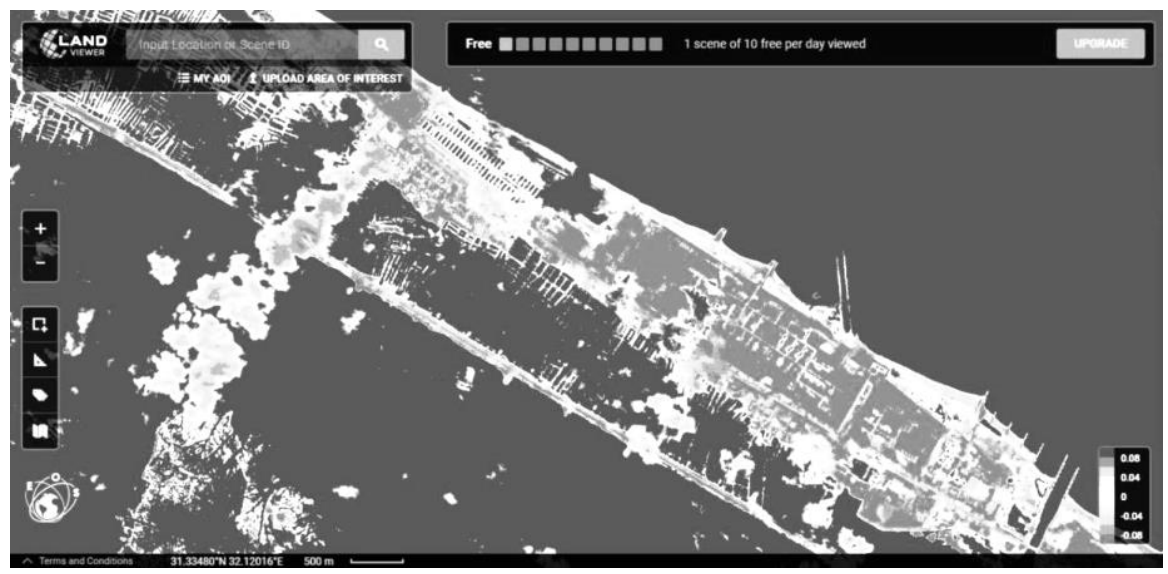

Figure 22.b: Satellite image for the study area dated 23/2/2018

Figure 22: Verification of shoreline evolution: (a) surveyed shoreline, (b) satellite image for the shoreline

\section{CONCLUSIONS}

- Protective and industrial marine structures which are constructed on the north coast of Egypt may cause negative impact on shoreline evolution, coastal water quality, fisheries and all marine resources.

- In this research, the importance of applying ICZM on Egyptian's coasts is studied.

- The shoreline in front of ZOHR gas processing plant, west of Port Said city, Egypt, was chosen as a case study.

- The study included the impact of constructing marine structures (flare stacks' causeways and temporary cofferdams) on shoreline evolution.

- Three methods for investigating shoreline of study area had been followed: numerical modeling using LITPACK one-line model; surveying monitoring program; and verification using satellite images, and the followings are concluded:

1. The results of the One-line numerical model showed that net sediment transport direction in the surf zone of the studied area is moving west to east.

2. For simulation period of 14 years, results showed obvious erosion to the east of both causeways which minimize the distance between the shoreline and the fence of the new treatment plant to a critical value.

3. In the two causeways configuration, the structures induce potential coastline erosion in the eastern zone within a limited distance of about $1150 \mathrm{~m}$ eastward of first constructed causeway.

4. The decision of constructing a temporary cofferdam had been taken after finalizing the numerical model. The early plan of construction considered that the temporary cofferdam shall be constructed after finishing the second flare stack causeway in 2018.

5. A shoreline monitoring program had been implemented for the study area for a period of 11 months (the first six surveying for the first causeway and the temporary cofferdam only, and the 
seventh surveying for all marine structures within study area).

6. A verification study using satellite images had been performed for the evolved shoreline showed that the surveyed shorelines are quite matched with these obtained from satellite images at different dates of comparison.

7. The marine structures in front of ZOHR project affect the original shoreline and parts of the shoreline retreat to critical distances to the plant fence.

\section{RECOMMENDATIONS}

- Mitigation measures are necessary for avoiding shoreline retreats in order to preserve the distance between plant fence and the evolved shoreline.

- It is recommended to establish ICZM plan for this study area to maintain the shoreline stability, preserving El Manzala Lake Inlet, coastal water quality, fisheries and all marine resources.

- It is highly recommended to extend the numerical model to include several scenarios of mitigation measures including beach nourishments, groins, detached breakwaters ... etc.

- It is recommended to extend the monitoring program for enough periods after the removal of the temporary cofferdam.

- It is suggested, if possible, to use open piled structures for the future similar projects to allow littoral sediment transport with small impact on shoreline evolution.

- Setting regulations to restrict development in vulnerable areas such as restrictions on set-back line for new developments at low-lying areas.

\section{REFERENCES}

[1] Ahmed, A.S.M., (2006), "Numerical Model as a Tool to Investigate Coastal Problems in Egypt", Tenth International Water Technology Conference, Alexandria, Egypt, pp 933-944.

[2] Ahmed, M. T., (2012), "Analysis and Modeling of Long-term Shoreline Changes and Alongshore Sediments Characteristics on the Nile Delta Coast", Ph.D. Thesis, Tokyo University.

[3] Cicin-Sain, B., (1993), "Sustainable Development and Integrated Coastal Management". Ocean \& Coastal Management $21,11-43$.

[4] Dabees, M. and Kamphuis, W., (1998), "Oneline, a Numerical Model for Shoreline Change". International Conference in Coastal Engineering, Copenhagen, Denmark, pp 2668-2681.

[5] Dewidar, K.M. and Frihy, O.E., (2010), "Automated Techniques for Quantification of Beach Change Rates Using Landsat Series along the North-Eastern Nile Delta, Egypt", Journal of oceanography and marine science, 1(2), pp 28-39.

[6] El-Asmar, H.M.; El-Kafrawy, S.B., and Taha, M.M.N., (2014), "Monitoring Coastal Changes along Damietta Promontory and the Barrier Beach toward Port Said East of the Nile Delta, Egypt", Journal of coastal research, 30(5), pp 993-1005.

[7] El-Sharnouby, B.A., El-Alfy, K.S., Rageh O.S., and El-Sharabasy, M.M., (2015), "Coastal Changes along Gamasa Beach, Egypt", Journal of coastal zone management, 17(2).

[8] Fabbri, K.P., (1998), "A methodology for supporting decision making in integrated coastal zone management". Ocean \& Coastal Management 39, 51-62.

[9] Frihy, O.E and Debes, E.A., (2011), "Beach and Nearshore Morphodynamics of the Central-Bulge of the Nile Delta Coast, Egypt", Journal of environmental protection, 1(2), pp 33-46.

[10] Frihy, O.E., Debes, E.A., El Sayed, W.R., (2003), " Processes reshaping the Nile delta promontories of Egypt: pre- and postprotection". Geomorphology 53, 263-279.

[11] Kemp, J.A., Coates, T.C., Head, R., and Harcourt, J.S., (2007), "Successful Beach Modeling, Monitoring and Management for a Large LNG Facility", Sixth International Symposium on Coastal Engineering and Science of Coastal Sediment Processes, New Orleans, Louisiana.

[12] Kenchington, R. and Crawford, D., (1993), "On the Meaning of Integration in Coastal Zone Management". Ocean \& Coastal Management 21, 109-127. 
[13] LAND VIEWER, web site: https://eos.com/landviewer.

[14] Mahdy, M.Y. and Tolba, I.R., (2012), "Assessment of Coastal Problems along the Northern Coast of Sinai Peninsula", Eighth International Conference on Coastal and Port Engineering in Developing Countries, Chennai, India , pp 738-749.

[15] White, K. and El Asmar, H.M., (1999), "Monitoring Changing Position of Coastlines Using Thematic Mapper Imagery, an Example from the Nile Delta", Journal of geomorphology, 29, pp 93-105.

"الإدارة المتكاملة للمناطق الساحلية فى شمال مصر"

ملخص البحث

تعتبر المناطق الساحلية من بين أكثر المناطق تعدادا بالسكان وأكثرها استغلالا ومن أكثر النظم الإيكولوجية المعرضة للخطر في العالم. إن فهم وإدارة

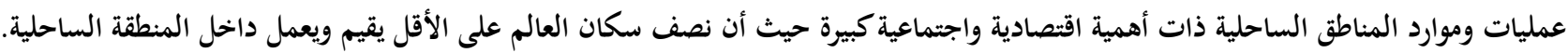

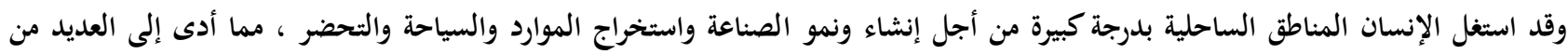

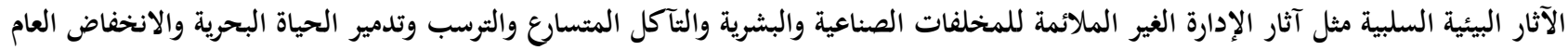

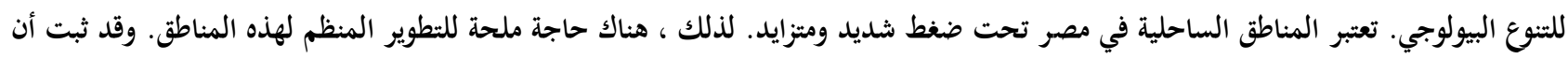

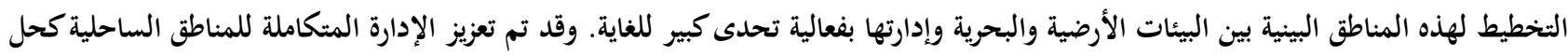

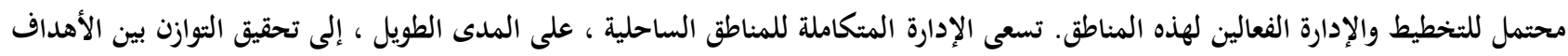

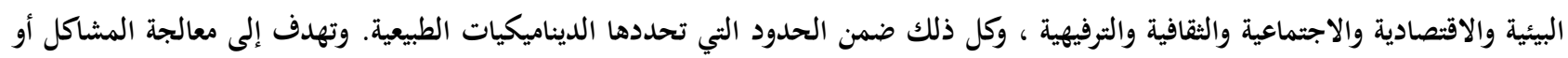

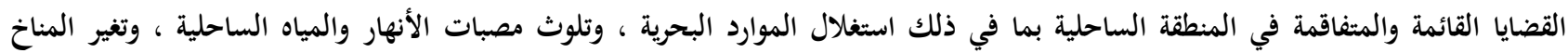

$$
\text { وارتفاع مستوى سطح البحر ، والتآكل الساحلى. }
$$

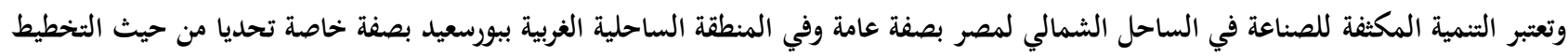

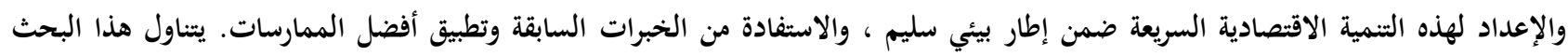

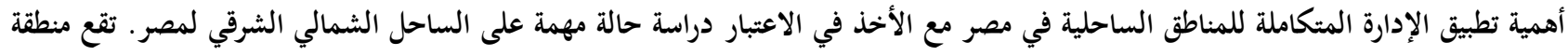

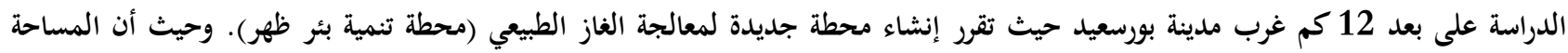

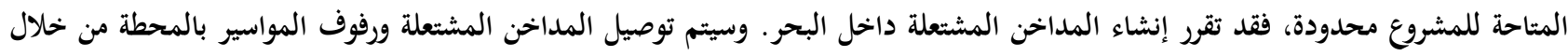

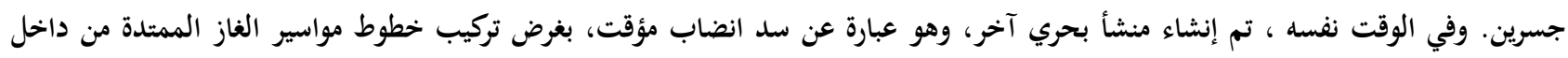

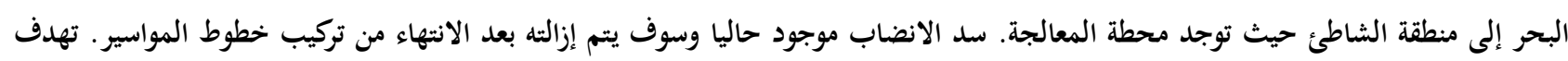

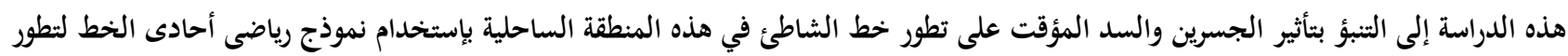

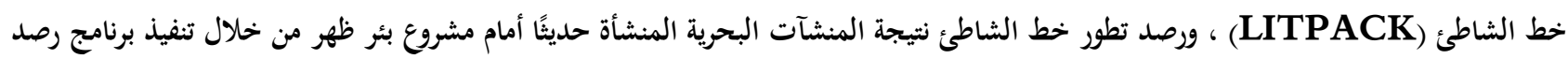

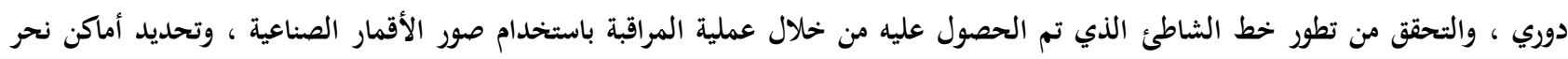

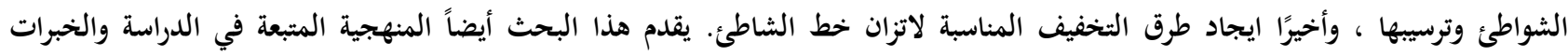

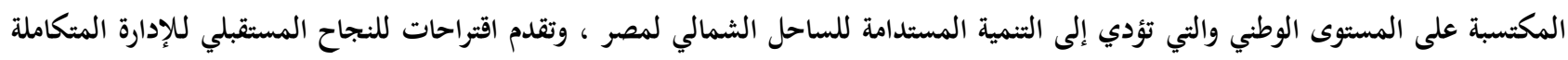
للمناطق الساحلية في مصر وتدعو إلى زيادة الاهتمام عند التخطيط للتنميات المستقبلية. 